\title{
Cloning and characterization of a novel oocyte-specific gene Fbos encoding an F-box protein in rainbow trout (Oncorhynchus mykiss)
}

\author{
Lei Wang \\ West Virginia University
}

Follow this and additional works at: https://researchrepository.wvu.edu/etd

\section{Recommended Citation}

Wang, Lei, "Cloning and characterization of a novel oocyte-specific gene Fbos encoding an F-box protein in rainbow trout (Oncorhynchus mykiss)" (2009). Graduate Theses, Dissertations, and Problem Reports. 2828.

https://researchrepository.wvu.edu/etd/2828

This Thesis is protected by copyright and/or related rights. It has been brought to you by the The Research Repository @ WVU with permission from the rights-holder(s). You are free to use this Thesis in any way that is permitted by the copyright and related rights legislation that applies to your use. For other uses you must obtain permission from the rights-holder(s) directly, unless additional rights are indicated by a Creative Commons license in the record and/ or on the work itself. This Thesis has been accepted for inclusion in WVU Graduate Theses, Dissertations, and Problem Reports collection by an authorized administrator of The Research Repository @ WVU. For more information, please contact researchrepository@mail.wvu.edu. 


\title{
Cloning and characterization of a novel oocyte-specific gene Fbos encoding an F-Box protein in rainbow trout (Oncorhynchus mykiss)
}

\author{
Lei Wang
}

Thesis Submitted to the

Davis College of Agriculture, Natural Resources and Design

at West Virginia University

in partial fulfillment of the requirements

for the degree of

\author{
Master of Science \\ In \\ Reproductive Physiology \\ Jianbo Yao, Ph.D., Chair \\ E. Keith Inskeep, Ph.D. \\ Janet Tou, Ph.D.
}

Morgantown, WV

2009

Keywords: Oocyte-specific gene, F-box protein, vitellogenesis, rainbow trout 


\begin{abstract}
Cloning and characterization of a novel oocyte-specific gene Fbos encoding an F-Box protein in rainbow trout (Oncorhynchus mykiss)

Lei Wang
\end{abstract}

Oocyte-specific genes play critical roles in oogenesis, folliculogenesis and early embryonic development. Through analysis of expressed sequence tags (ESTs) from a rainbow trout oocyte cDNA library, we identified a novel transcript which is represented by multiple ESTs derived only from the oocyte cDNA library. Analysis of tissue distribution of the novel Fbos gene by reverse transcription polymerase chain reaction revealed that the novel gene is only expressed in unfertilized oocytes but not in 10 somatic tissues examined. Northern blot analysis showed the transcript size is approximately $2.1 \mathrm{~kb}$. The full-length cDNA sequence for the novel gene Fbos was obtained by assembly of sequences from the EST clones and a 5 'end sequence from a 5'RACE product. The complete cDNA is $1966 \mathrm{bp}$ in length containing an open reading frame, which encodes a predicted protein of 514 amino acids. The amino acid sequence does not share homology with any known proteins in the NCBI databases. However, a search of the Pfam protein database revealed that the protein contains an F-box motif at the $\mathrm{N}$-terminus, indicating that this novel oocyte-specific protein is a member of the rapidly expanding family of F-box proteins. F-box proteins are components of ubiquitinligase complexes, in which they bind substrates for ubiquitin-mediated proteolysis. F-box proteins have also been associated with cellular functions such as signal transduction and regulation of the cell cycle. Real time PCR analysis of the mRNA expression of the novel gene during oogenesis and early embryogenesis demonstrated that the expression of the novel gene is extremely high during early previtellogenesis and decreases dramatically after fertilization. This result is confirmed by in situ hybridization which showed that the novel transcript is highly abundant in early previtellogenic oocytes. Western blot analysis using antibodies generated against a synthetic peptide of the novel protein detected a protein band of $\sim 51 \mathrm{kDa}$ in a protein sample prepared from oocytes. The specific expression of this gene in oocyte and its developmental pattern of expression suggest a role for this novel gene in the regulation of early oocyte or follicle development. 


\section{Acknowledgements}

I would like to thank my committee for their support and guidance. I would like to thank all my fellow graduate students, past and present. Especially, I would like to thank Dr. Yao, my advisor, for always been supportive. I hope I have shared with you a fraction of what I have learned from you. Finally, I would like to thank my family, mom, dad, and my grandparents, nainai yeye and laolao, thank you for loving me so much. Without your support, I could never have finished this degree. 


\section{Dedication}

\section{To Grandpa}




\section{Table of Contents}

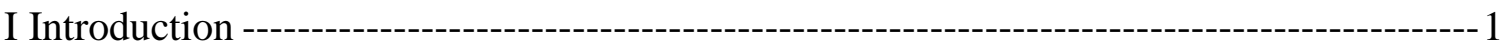

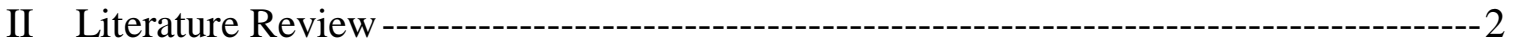

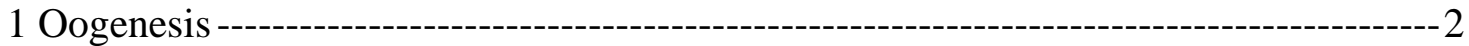

A Function of Gonadotropins and MIH in vitellogenesis---------------------2

B Maturation Promoting Factor ---

2 Important factors in regulation of folliculogenesis and oocyte maturation --------------4

A Formation and early development of primordial follicles ------------------4

B Development of primary follicles and proliferation and differentiation of ovarian cells ------or

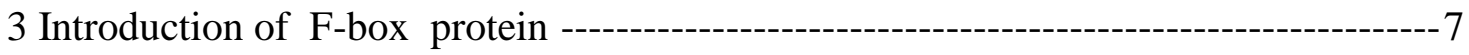

A Distribution and Classification of F-box protein ---

B Function of F-box proteins--Ubiquitination and Neddylation------------------8

III Objectives of the Study------ 11

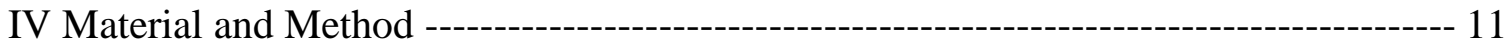

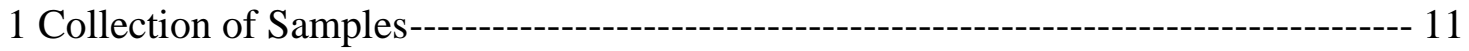

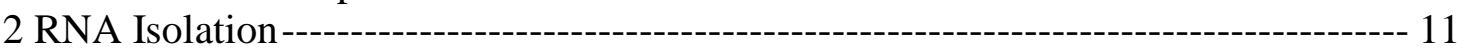

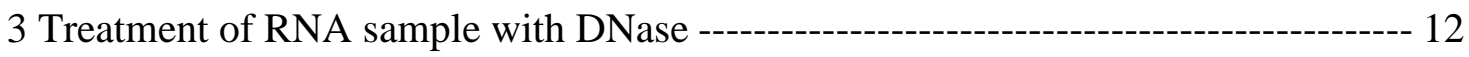

4 Reverse-Transcription Polymerase Chain Reaction ----------------------------- 12

5 5' RACE (Rapid Amplification of cDNA End) ------- 12

6 Cloning of Fbos gene into E.coli by chemical transformation ----------------- 12

7 Preparation of Digoxingenin (DIG) labeled DNA and RNA probe ------------------ 13

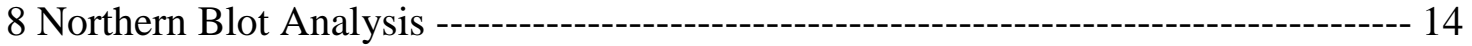

9 Western Blot analysis --------ons 14

10 Preparation of paraffin sections for Rainbow Trout oocytes ---------------------- 15

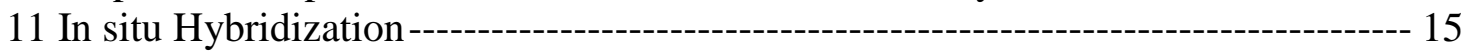

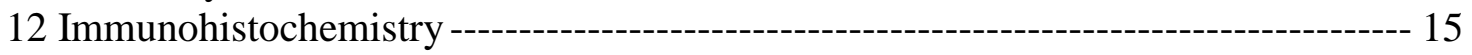

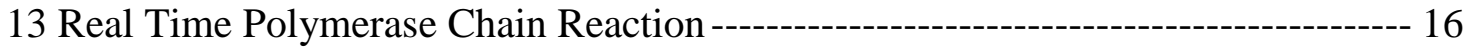

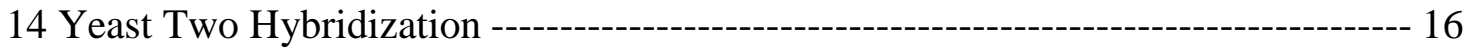

A $\beta$-galactosidase assay ------------o---o- 17

V Results -- 17

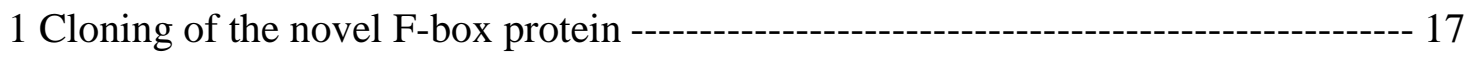

2 Sequence Analysis of Fbos gene ------------------------------------ 18

3 Quantitative analysis of Fbos mRNA expression during oogenesis and early embryonic development -------------------------------------------------- 18

4 Protein expression analysis of Fbos in different stages of oogenesis ---------------- 18

5 Localization of Fbos mRNA and protein in different stages of oocytes------------- 18

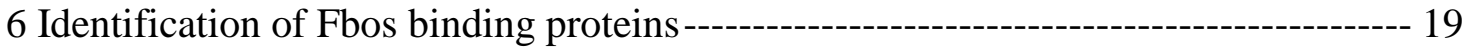

VI Discussion------os 19

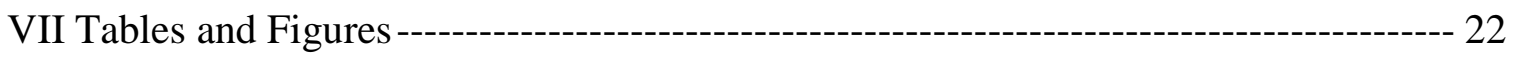

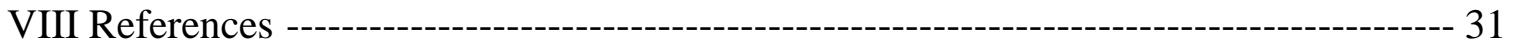




\section{List of Tables}

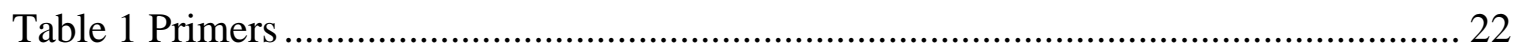

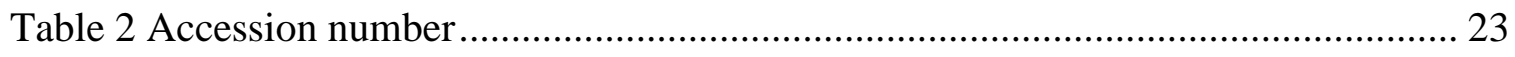




\section{List of Figures}

Figure 1 Consensus sequences of F-box proteins …………......................................... 24

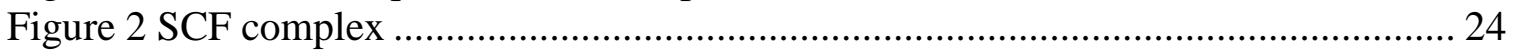

Figure 3 RT-PCR analysis of tissue distribution of Fbos ............................................. 24

Figure 4 Northern blotting analysis of Fbos mRNA from early vitellogenic oocytes...... 25

Figure 5 Full length cDNA sequence of Fbos ............................................................. 27

Figure 6 Real-Time PCR analysis of Fbos mRNA levels in different developmental

stages of oocytes and early embryos........................................................................... 28

Figure 7 Western Blotting analysis of Fbos in different stages of oocytes ...................... 28

Figure 8 In situ hybridization analysis of Fbos mRNA localization ................................ 29

Figure 9 Immunohistochemistry analysis of Fbos protein localization ............................. 30

Figure $10 \beta$-galactosidase activity assay of positive colonies from Yeast Two

Hybridization analysis …………………………………......................................... 31 


\section{Introduction}

Commercial aquaculture production depends on the control of reproductive function under domestication. One of the most important prerequisites for domestication is to acquire high quality gametes (Constantinos C. Mylonas 2009). The ability of the egg to be fertilized and develop into a heath embryo is defined as fish egg quality and oogenesis plays a key role in control of the egg quality (Bobe and Labbé 2009). After years of studying, rainbow trout is featured in thousands of scientific papers. Because of the transparency of the large eggs, ease of manipulation and large amount of molecular materials, rainbow trout ovary has become the ideal model for various types of research in reproductive physiology (Thorgaard et al. 2002). Identifying the molecular markers of oogenesis, ovarian folliculogenesis, fertilization and early embryonic development of rainbow trout will help aid the selection of broodstock.

The finely orchestrated development and maturation of the oocyte have been the focus of studies in which essential genes have been identified. The initial stages of oogenesis are featured by a short period of intense RNA synthesis just prior to a long period of vitellogenesis, which is characterized by an accumulation of yolk reserves. Vitellogenesis is regulated by hepatic production of lipoproteins and endogenous protein post-translational modification, including phosphorylation, acetylation and ubiquitination.

Ubiquitin modification system can affect the activity, localization, sorting and stability of proteins. The ubiquitin ligase E3 is one of the three enzymes involved in ubiquitination and it can be classified into three subfamilies and an F-box protein is one of the components of the most important E3 subfamily, the SCF complex (Varshavsky 1997). SCF complex is generally the term used to Skp1, Cullin and F-box complex in which F-box proteins play a key role in substrate recognition. F-box proteins, as a critical part of SCF complex, are determinants for 
controlling SCF substrate selection and are recognized as key in many pathways of cell signaling transcription and the cell cycle (Kong et al. 2000; Margottin-Goguet et al. 2003). Several oocytespecific genes have proved to be regulated by F-box proteins, such as Emi1 and cyclineB (Kong et al. 2000; Margottin-Goguet et al. 2003). Another F-box protein, Fbxw15, which was identified in mouse ovary has been found as an oocyte-specific gene (De La Chesnaye et al. 2008). To better understand the roles of F-box proteins in oogenesis and embryogenesis in fish, the cDNA sequence for oocyte-specific F-box in rainbow trout (Fbos) was characterized and the expression profiles and subcellular localizations during oogenesis and early embryonic development were evaluated. 


\section{Literature Review}

\section{Oogenesis}

Primordial follicles are selected from the pool and enter into a growth phase. Those recruited primordial follicles arrest in prophase of meiosis I, then grow into primary follicles, secondary follicles, and finally antral follicles. Meanwhile, the oocytes are fully developed and ready for the resumption of meiosis which is defined as the completion of meiosis I, followed by progression to metaphase of meiosis II which is the hallmark of oocyte maturation (Nagahama and Yamashita 2008; Rajkovic 2004). In fish, although the oocyte is arrested in the first meiotic prophase, it can be activated transcriptionally by 3 mediators, gonadotropin (LH, luteinizing hormone and FSH, follicle stimulating hormone), maturation-inducing hormone (MIH; 17 2,20 $\beta$-dihydroxy-4-pregnen-3-one; $17 \alpha, 20 \beta$-DP) and maturation-promoting factor (MPF) (Lessman 2009). Two kinds of gonadotropins, FSH and LH are released from the pituitary and both of them share similar structure and function with their mammalian counterparts (Planas et al. 2000).

\section{A Function of Gonadotropins and MIH in vitellogenesis}

In fish, preovulatory oocyte development includes two major phases; one is vitellogenic growth, in which, the oocyte arrested in prophase of meiosis I but with the massive growth of diameter. The other phase is the final maturation of the oocyte, which is a prerequisite for fertilization (Nagahama and Yamashita 2008). FSH has the major regulatory role in the vitellogenic growth of follicles by stimulating the secretion of estradiol-17 $\beta$ (E2) from the ovarian layers. Testosterone, produced by thecal cell layer, is converted to E2 in granulosal cell layer by aromatase, key enzyme, in this conversion reaction. FSH can enhance the activity of aromatase in granulosal cells. Also, E2 is considered to play the dominant role to regulate 
vitellogenin biosynthesis in liver. During the early development of oocyte, the plasma vitellogenin concentration increases steadily along with the rising concentration of E2. At that time, vitellogenin is the major blood protein. The high concentration of vitellogenin is essential for the preovulatory oocytes, became growth of the ovary requires massive deposition of vitellogenin protein in thousands of oocytes that can comprise $25 \%$ of the body weight. (Sumpter and Jobling 1995).

$\mathrm{LH}$ is involved in oocyte maturation by stimulating the production of $17 \alpha, 20 \beta$-DP (17 $\alpha, 20 \beta$-dihydroxy-4-pregnen-3-one). The biosynthesis pathway of $17 \alpha, 20 \beta$-DP initiates with the synthesis of the steroid precursor pregnenolone through wide-chain cleavage of cholesterol by cholesterol side-chain-cleavage cytochrome P450. Pregnenolone is converted to progesterone or to 17 a -hydroxypregnenolone and then converted to 17 a -hydroxyprogesterone, the precursor of $17 \alpha, 20 \beta$-DP, by the rate limiting enzyme $20 \beta$-hydroxysteroid dehydrogenase (20 $\beta$-HSD) in thecal cell layer. $17 \alpha$, $20 \beta$-DP is one of the most important hormones produced by ovarian layers. According to the two-cell model in fish, the precursor 17 a hydroxyprogesterone transverses the basal lamina from thecal cell layer to granulosal cell layer. Granulosal cell layer produces the key enzyme $20 \quad \beta$-HSD which converts 17 a hydroxyprogesterone to $17 \alpha, 20 \beta-\mathrm{DP}$, and the production of $20 \beta-\mathrm{HSD}$ is greatly stimulated by gonadotropin (Nagahama 1994; Young et al. 1986).

\section{B Maturation Promoting Factor}

MPF consists of $\mathrm{Cdc} 2$ and cyclin B proteins and it plays a pivotal role in oocyte maturation by phosphorylating many proteins involved in nuclear membrane breakdown, chromosome condensation and microtubular reorganization (Kajiura-Kobayashi et al. 2000). In 
Xenopus, the activation and formation of MPF complex is similar to that in mammalian species. Cdc2 and the presynthesized cyclin B form a pre-MPF complex in immature oocytes. Upon the stimulation of $\mathrm{MIH}$, stimulatory G-protein is inhibited, which leads to the decrease in intracellular cAMP and consequently decreases the activity of protein kinase A. Inactive protein kinase A fails to activate Myt1, the repressor of cdc25, and leads to phosphorylation of $\operatorname{cdc} 25$, which results in conversion from pre-MPF to MPF. Furthermore, MPF can induce activation of pre-MPF and finally forms a positive feedback activation loop. At the same time, the de novo synthesized cyclin B forms more pre-MPF with the pre-accumulating cdc2; these pre-MPF can be used to generate more mature MPF. In this pattern of MPF activation pathway, cyclin B and pre-MPF is preexisting in the oocyte (Nagahama and Yamashita 2008).

In some fish species such as carp, goldfish, catfish, zebrafish and others cyclin B proteins and pre-MPF are absent in immature oocytes. The mechanism of MPF activation and formation is initiated by the accumulation of monomeric cdc2 without presynthesized cyclin B. Before the onset of germinal vesicle breakdown (GVBD), cyclin B protein is de novo synthesized and in response to the MIH signal triggering the transduction pathway of cAMP and PKA, the cyclin B binds to monomeric cdc2 forming active MPF after phosphorylation of cdc2 (Tanaka and Yamashita 1995).

The species-specificity of MPF formation and activation remains to be further elucidated. For species like freshwater perch, axolotl and rainbow trout, it is reported that cyclin B is present in immature oocytes (Basu et al. 2004; Qiu et al. 2008; Vaur et al. 2004). According to Basu et al., although axolotl has activated pre-MPF during oocytes maturation, immature oocytes have very low pre-MPF and show slow manner of cdc2 activation. This MPF activation mechanism in axolotl oocyte represents an intermediate category between the goldfish and the Xenopus model 
(Vaur et al. 2004). Similar to the axolotl, intermediate mechanisms might be employed in the perch and rainbow trout, which have very low pre-MPF in immature oocytes.

Taken together, upon hormonal stimulation, oocytes arrested in prophase meiosis I are released. Resumption of meiosis is initiated by activation of maturation promoting factor. The catalytic subunit of MPF, cyclin B, then phosphorylates several substrates which play critical roles in oocyte maturation. Cyclin B especially is involved in oocyte nuclear maturation such as germinal vesicle breakdown, chromosome condensation, microtubular reorganization and spindle formation. These physiological changes inside the oocyte nucleus lead to exit from meiosis I arrest, and the resumption of intensive transcriptional and translational activity (Kishimoto 1994).

\section{Important factors in regulation of folliculogenesis and oocyte maturation}

The carefully orchestrated oocyte development and maturation have been the focus of studies in which essential genes have been identified. These genes encode a collection of transcription factors, mRNA binding proteins, and secreted proteins that are required for normal germ cell development (Zheng and Dean 2007). To date, although several counterparts of those genes are found in non-mammalian vertebrate models, such as zebra fish, Xenopus and rainbow trout etc., molecular mechanisms of folliculogenesis and oocyte maturation remain under investigated among different species.

\section{A Formation and early development of primordial follicles}

The formation and early development of primordial follicles have gained attention in recent years. Factor of germline alpha (Figla), the transcription factor regulating the expression of zona pellucida genes 1, 2 and 3, was first identified by Liang et al. (1997). It encodes an 
oocyte-specific basic helix-loop helix (bHLH) domain which can bind with E-box in each of the zona promoters (Liang et al. 1997; Soyal et al. 2000) .

Zona pellucida genes encode important structural glycoproteins that form the extracellular zona pellucida. By establishing mouse lines lacking Figla, Soyal et al. (2000) confirmed that Figla-null female mice not only lack zona transcripts, but also failed to form primordial follicles. These studies implicate Figla's crucial requirement in the initial formation of primordial follicles. Also, the persistence of Figla expression from early embryonic day 13 (E13) into adulthood indicates that it may regulate at least two sets of genes required for oocyte and early embryonic survival, respectively (Soyal et al. 2000). In Japanese rice fish medaka (Oryzias latipes), Figla homolog has been cloned and identified showing 53\% identity to the bHLH region. The expression of medaka Figla is restricted to the smallest oocytes during early oogenesis indicating that this gene may play an equivalent role in fish species (Kanamori 2000).

Other germ-cell-specific basic helix-loop-helix transcription factors are Sohlh1 and Sohlh2 (Ballow et al. 2006). Sohlh1 regulates many genes that are required for early oocyte development. A homeobox gene $\operatorname{Lhx} 8$ is likely a direct transcriptional target of Sohlh1; also with the help of Figla, Sohlh 1 may have the ability to directly regulate Zp1 and Zp3. In Sohlh1 knockout mice model, a number of oocyte-specific genes that play important roles in early oocyte development are down-regulated, such as Figla, GDF9 and Nobox (Pangas et al. 2006).

Nobox (Newborn ovary homeobox) is an essential transcriptional factor for early folliculogenesis. It is an oocyte-specific homeobox gene expressed in germ cell cysts, primordial and growing oocytes (Suzumori et al. 2002). In Nobox null mice model, although the normal primordial follicles were still formed in knockout female, the growth of primary follicles are severely compromised (Rajkovic 2004). Also in knockout newborn mouse ovary, the transcripts 
of Mos, Oct4, ZarI, GDF9 and BMP15 were down-regulated. Choi et al. suggested that Nobox either directly or indirectly regulates a set of genes that have key roles in oogenesis (Choi et al. 2007). Based on the recent studies using genetically specific knockout mice, Figla initiates formation of primordial follicles with the help of Sohlh1, and Nobox is involved in the progression to primary follicles. The networks formed by these transcription factor genes are essential for early folliculogenesis by regulating the expression of each other and down steam targets (Zheng and Dean 2007).

\section{B Development of primary follicles and proliferation and differentiation of ovarian cells}

Folliculogenesis involves not only the careful orchestration of developmental programs in oocytes and surrounding somatic cells, but also the intimate interaction between the two cell types (Matzuk et al. 2002). Members of transforming growth factor beta (TGF- $\beta$ ) super family function as paracrine and autocrine factors to exert important effects regulating developmental processes in the sub-cellular environment (Bilezikjian et al. 2006). Members of TGF- $\beta$ superfamily have been characterized into three major subfamilies, based on their structural homologies: 1. activins/inhibins; 2. bone morphogenetic proteins (BMP); and 3. TGF- $\beta$ (Heldin et al. 1997; Massague 1998). As commonly expressed in mammalian ovary, TGF- $\beta 1$ and other two isoforms, $\beta 2$ and $\beta 3$ have been detected in several fish species including: rainbow trout, goldfish, carp, hybrid striped bass, European eel and Siberian sturgeon (Hardie et al. 1998; Harms et al. 2000; Laing et al. 2000; Mulheron et al. 1991; SchmidP and vanderPuttenH 1994; Zhan and Jimmy 2000). There are reports showing the conflicting role of TGF- $\beta$ in folliculogenesis and oocyte maturation in mammals and it is poorly understood in fish. However, BMP15 and GDF9, members of bone morphogenetic proteins, have captured 
increasing attention and changed the traditional views on the active role of oocyte in controlling folliculogenesis (Coskun and Lin 1994; Feng et al. 1988; Singh et al. 1993).

As transcription factors, GDF9 and $B M P 15$ are thought to play an active paracrine role in controlling the differentiation of surrounding somatic cells by oocytes (Elvin et al. 1999a; Matzuk et al. 2002; Vitt and Hsueh 2002).

GDF9 has been cloned and detected in diverse mammalian species (Aaltonen et al. 1999; Bodensteiner et al. 1999; Dong et al. 1996). It is exclusively expressed in oocyte from early primary follicles to early antral follicles; after fertilization it can still be detected up to 8-cell stage in cattle (Sendai et al. 2001). In GDF9 knockout mice, the disruption of GDF9 expression led to infertility due to arrested development at primary follicle stage with the absence of the thecal cell layer and incompetence in oocyte meiotic division (Carabatsos et al. 1998; Dong et al. 1996). Also in antral follicles, FSH induces granulosa cell differentiation which is partly blocked by GDF9. Therefore the cumulus cell layer was undifferentiated; the expansion of cumulus cells surrounding the oocyte was disrupted in GDF9 null mice (Elvin et al. 1999b).

$B M P 15(G D F 9 b)$ is a homolog of GDF9, with which it shares $52 \%$ amino acid identity. Similar to GDF9, BMP15 is an oocyte-specific gene with the similar expression pattern as GDF9 (Dube et al. 1998; Laitinen et al. 1998). However, BMP15 null mice show that BMP15 is not as essential for folliculogenesis as its counterpart GDF9. Disruption of BMP15 expression did not greatly affect early folliculogenesis, but to some degree it can reduce the ovulation level (Yan et al. 2001).

In fish, GDF9 and BMP15 have been cloned in European sea bass (Dicentrarchus labrax) and zebrafish (Bodensteiner et al. 1999; Liu and Ge 2007). Intriguingly, unlike mammals, in zebrafish BMP15 and GDF9 had different expression patterns. BMP15 was expressed from 
follicle development to oocyte maturation with no significant difference among different stages (Clelland et al. 2007). However, GDF9 is expressed predominantly in primary follicles, but gradually declined with follicular development (Ge 2005). Also, in zebrafish, BMP15 was found in other somatic tissues such as heart, liver, gut, brain, and muscles (Clelland et al. 2007); in contrast GDF9 was expressed exclusively in oocyte. Ge (2005) summarized the proposed roles of BMP15 in zebrafish oogenesis in 2005; it showed that BMP15 may have effects on regulating the expression of LH receptor, $20 \beta$-HSD and G-protein-coupled receptors, which are all very important factors in hormonal regulated oogenesis in fish ovary.

\section{Introduction of F-box protein}

Gametogenesis is an orchestrated process of the stringent regulation of numerous factors in transcriptional or/and translational activities. Translational control is essential for determination of cell cycle and cellular functions during the development of multicellular organisms. Temporal and spatial control of post-translational protein modification and protein degradation is of fundamental importance to ensure the achievement of development. Protein modification mechanisms including ubiquitination and neddylation have recently showed their crucial roles in the regulation of a wide range of cellular processes especially in gametogenesis. As an important component and key subunit of ubiquitin enzyme E3, F-box protein has captured increasing attention in different cellular processes in diverse species.

\section{A Distribution and Classification of F-box protein}

F-box domain and F-box protein family are named after human cyclin F which was found in 1994 by Bai et al. (Bai et al. 1994). In a short period of time, F-box domain was universally known as a common motif which is required for protein-protein interaction (Bai et al. 1996). In different species, F-box protein is found in both cytoplasm and nucleus (Kipreos and Pagano 
2000). There are more than 326 predicted F-box sequences in C. elegans, 22 in Drosophila, 68 in human beings; it also has been found in plants such as rice and Arabidopsis and recently reported in mice ovary (De La Chesnaye et al. 2008). In reproductive development of Arabidopsis the unusual floral organs gene which contains F-box domain plays a crucial role in flower development and has a complex expression pattern (Durfee et al. 2003). In mice, it was reported that one F-box protein, Fbxw15, which is exclusively expressed in oocyte, might have potential functions in oogenesis (De La Chesnaye et al. 2008). It is revealed that F-box proteins may play important roles in both plant and animal reproductive systems.

The F-box protein motif contains approximately 50 conservatived amino acids (Figure 1; (Kipreos and Pagano 2000). The F-box motif is commonly found in amino-terminal; however, in carboxyl-terminal there are often secondary motifs, which are widely believed to have the protein binding activities. The two most common secondary motifs are WD (Trp-Arp) repeats and leucine rich region (LRR). According to the structure of the motifs, F-box proteins can be classified into three categories: FBXL, a protein containing an F-box and LRR; FBXW, a protein with an F-box and WD repeats; FBXO, a protein with an F-box and unknown motifs (Cenciarelli et al. 1999). Substrate screening showed that not only F-box proteins with WD and/or LRR can bind with the protein substrates, but the FBXO subfamily as well (Chiaur et al. 1999).

\section{B Function of F-box proteins--Ubiquitination and Neddylation}

Ubiquitin system of intracellular protein degradation governs the abundance of important regulatory proteins (Craig and Tyers 1999). Most proteins with misfolded domains are degraded by the ubiquitin proteolytic system. Ubiquitination complex once interacting with the target protein, covalent attachment will be made and a polyubiquitin chain will be formed and conjugated onto the target. Labeled by the polyubiquitin chain, the target protein can be 
captured and degraded by 26S proteasome (Hershko and Ciechanover 1998). Activation of the ubiquitin system is an enzymatic signaling cascade.

Upon activation, the ubiquitin activating enzyme E1 forms a linkage between a cysteine residue on itself and the carboxy-terminal of ubiquitin which then be transesterified onto a cysteine residue of ubiquitin conjugating enzyme E2. With the help of ubiquitin ligase E3, the linked ubiquitin is transferred to the substrate protein forming a covalent bond (Hershko and Ciechanover 1998). The ubiquitin ligase E3 can be classified into three subfamilies and F-box protein is one of the components of the SCF complex, the most important E3 ligase subfamily (Varshavsky 1997). SCF complex is the term generally used to refer to Skp1, Cullin and F-box complex in which F-box proteins play a key role in substrate recognition (Figure 2). The first SCF complex pathway was identified in yeast and it appears to recognize and ubiquitinate only phosphorylated substrates. Apart from regulating protein phosphorylation networks and proteolytic degradation, SCF complex also regulates a great number of cellular pathways by shifting substrate specific adaptor subunits, which are F-box proteins (Craig and Tyers 1999). Although the SCF complexes might have different components due to different functions, the mechanism of how SCF pathways work is similar: F-box proteins recognize the specific target protein substrates through the additional secondary motifs on the carboxyl-terminal of F-box proteins (Figure 2) (Jianping Jin 2005).

The function of SCF complex is determined by F-box protein, which was involved in the control of cell cycle, signal transduction transcription and development (Willems et al. 2004). A yeast gene encoding SKP1 protein containing an F-box motif was identified and the mutants of SKP1 arrested cells in G1 or G2 indicated that F-box protein SKP1 was required for both G1/S and G2/M transitions (Bai et al. 1996). CDC4 (also known as Fbw7) proteins containing WD40 
repeats, binds to phosphorylated Sic1 and Swi5, which control expression of Sic1 cluster genes: EGT2, DCD6 and RME1. Sicl cluster genes inhibit CDC28 kinases and their destruction is required for S phase entry of mitosis. Therefore, SCF complex with CDC4 as F-box subunit is believed to be involved especially in controlling the cell cycle (Kishi et al.). cIAP inhibits the caspase activity by targeting pro-apoptotic molecules for proteasomal degradation. In 2006, Chang et al. found that cIAP can interact with an F-box protein, Fboxo7. Fboxo7 is one of the 69 F-box proteins found in human beings, which interact with cIAP and eventually promote the degradation of cIAP (Kipreos and Pagano 2000). Taken together, F-box proteins with their specific substrate proteins involved in a wide range of ubiquitin-mediated proteolysis in various cellular processes.Nedd8 (Neural precursor cell-expressed developmentally down-regulated eight) is a small ubiquitin-like protein with $53 \%$ identity to ubiquitin, which is conserved among various species (Kamitani et al. 1997). In SCF complex, Cullin is modified by Nedd8 to enhance the activity of the whole ubiquitin ligase E3 complex (Deshaies 1999). There are several major differences between neddylation and ubiquitination: first and the most important, unlike ubiquitination, neddylation does not necessarily lead to proteasomal degradation of target proteins; second, it does not form polyprotein chains conjugated to the target proteins like ubiquitin; third, Nedd8 conjugated proteins appear to reside predominately in the nucleus (Kamitani et al. 1997). Recently several studies revealed more evidence for the interaction of the nedd8 and F-box protein pathway in cell cycle control and viability. The tumor suppressor p53 has been known as a central factor in the cellular response to stress. It functions as a transcription factor in response to DNA damage, oncogene activation, hypoxia and oxidative damage. In 2007, Abida et al. reported that an F-box protein $F B X O 11$ is a novel p53-inveracting protein, which promotes the neddylation of p53 to inhibit its activity without affecting its stability (Abida et al. 
2007). Emil and $C y c l i n B$ are under the regulation of F-box protein-governed ubiquitination (Kong et al. 2000; Margottin-Goguet et al. 2003). In oocyte development Emi1 and cyclinB are the critical factors involved in meiotic resumption of oocyte maturation. Recently Fbxw15an oocyte-specific F-box protein was identified in mouse ovary (De La Chesnaye et al. 2008).

In summary, F-box proteins as a critical part of SCF complex, are determinant for controlling SCF substrate selection and are recognized as key in many pathways of cell signaling transcription and the cell cycle. Further studies in this field to identify and characterize the substrates of the oocyte-specific F-box protein could provide insights into more precise molecular mechanisms governing oocyte development. 


\section{Objectives of the Study}

A rainbow trout oocyte cDNA library was constructed in the laboratory of Dr. JianboYao with the intention to indentify novel oocyte-specific genes that affect the oogenesis and early embryogenesis in rainbow trout. A novel gene has been discovered, which is represented by multiple ESTs derived only from the oocyte cDNA library The amino acid sequence does not share homology with any known proteins in the NCBI databases. However, a search of the Pfam protein database revealed that the protein contains an F-box motif at the $\mathrm{N}$-terminus, indicating that this novel oocyte-specific protein is a member of the F-box protein family. The aims of this study are: 1) Analysis of tissue distribution of the novel gene by reverse transcription polymerase chain reaction, 2) Determine the size and transcript number of the novel gene, 3) Determine the expression of this gene during oogenesis and early embryogenesis, 4) Localize the mRNA and protein of the novel gene in different stages of oocytes, 5) Study the protein expression of the novel F-box protein using specific antibody during vitellogenesis of rainbow trout oocytes, 6) Identify the substrate proteins that interact with the novel F-box protein. 


\section{Material and Method}

\section{Collection of Samples}

Ovarian samples were collected from female rainbow trout according to different stages of development. The stages of ovarian development in fish were determined based on morphological characteristics and the size of the oocytes as described by (Tyler et al. 1994). Ovaries were separated under microscopy into 5 stages: early-previtellogenesis ( $\mathrm{Vg} 0.5 \mathrm{~mm})$, late pre-vitellogenesis $(0.65 \mathrm{~mm})$, early-vitellogenesis $(0.65-1.1 \mathrm{~mm})$, med-vitellogenesis ( $(1.1-2.1)$ and late-vitellogenesis $(2.1-4.0 \mathrm{~mm})$. Fertilized oocytes were incubated at $13^{\circ} \mathrm{C}$ in a flow through system using a photoperiod of $12 \mathrm{hr}$ light-12 hr dark. Embryonic samples were collected at day 0, 4 and 7 after fertilization. Various tissues including heart, gill, testis, intestines, muscle, brain, kidney, ovary, liver, spleen and skin were collected from mature fish. All samples were quick frozen in liquid nitrogen and stored in $-80^{\circ} \mathrm{C}$ until use.

\section{RNA Isolation}

Extraction of total RNA from all the ovarian and somatic tissue samples was carried out according to manufacturer's protocol of Tri-Reagent (Molecular Research Center, Cincinnati,OH). All RNA samples were treated with RNase-free DNase (Promega Madison, WI) to remove DNA contamination. Poly-A-RNA was isolated from total RNA using biotinylated oligo-d (T)-probe and streptavidin attached to magnetic beads from the poly A tract mRNA isolation system (Promega Madison, WI).

\section{Treatment of RNA sample with DNase}

Six $\mu$ g of total RNA, $3 \mu$ of 10X DNase I buffer and $1 \mu$ of DNase I (Ambion) were added in one PCR tube and the volume was made up to $30 \mu l$. The mixture was gently mixed. After 25 minutes of incubation at $37^{\circ} \mathrm{C}, 5 \mu \mathrm{l}$ of resuspended DNase inactivation reagent was 
added and incubated for 2 minutes at room temperature. The tube was centrigfuged at 12,000 $\mathrm{g}$ for 2 minutes and the supernatant RNA was transferred to a fresh tube.

\section{Reverse-Transcription Polymerase Chain Reaction}

RT-PCR was used to amplify the Fbos gene from different tissues collected above. About 3 micrograms of DNase-treated total RNA from various tissues was used for first strand cDNA synthesis. One $\mu \mathrm{l}$ of Oligo (dT) 18 primer, $1 \mu \mathrm{l}$ of dNTP mix (10mM each) and $3 \mu \mathrm{l}$ of water were added to the DNase-treated RNA sample and incubated at $65^{\circ} \mathrm{C}$ for 5 minutes. Four $\mu \mathrm{l}$ of $5 \mathrm{X}$ first strand cDNA synthesis buffer, $2 \mu \mathrm{l}$ of $0.1 \mathrm{M}$ DTT and $1 \mu \mathrm{l}$ of Super-Transcript III reverse transcriptase (200U/ml, Invitrogen) were applied to the reaction. The mixture were gently mixed and incubated in $42^{\circ} \mathrm{C}$ for 50 minutes. The reaction was terminated by heating the samples at $70^{\circ} \mathrm{C}$ for 10 minutes in a PCR machine. Negative control reverse transcription reactions were conducted without reverse transcriptase to confirm no genomic DNA contamination. The RT product, first-strand cDNA was diluted by $80 \mu \mathrm{l}$ of water and was used as PCR template to amplify 524 bp fragment of the Fbos gene using gene specific primers (Table 1). PCR was performed in a $25 \mu \mathrm{l}$ reaction mix with the condition of a 5 min denaturation at $94^{\circ} \mathrm{C}$ followed by 30 cycles of $94^{\circ} \mathrm{C}$ for $30 \mathrm{sec}, 58^{\circ} \mathrm{C}$ for $45 \mathrm{sec}$, and $72^{\circ} \mathrm{C}$ for $30 \mathrm{sec}$, and a final extension at $72^{\circ} \mathrm{C}$ for 10 minutes. Trout $\beta$-actin gene was used as internal control to verify RNA quantity.

\section{5' RACE (Rapid Amplification of cDNA End)}

To obtain the 5' end of the cDNA sequence, 5' RACE was performed using the second generation 5'/3' RACE kit (Roche Diagnostics Indianapolis, IN) following the manufacturer's protocol. cDNA and A tailed cDNA or 5'RACE were synthesized following the protocol of the kit, with modification that used random primer were instead of the primer provided in the kit. Gene specific primers for nested PCR were designed (called SP1, SP2, SP3) in conjunction with 
d (T) anchor from the kit and PCR anchor primers (complimentary to dT anchor sequence). The specific PCR product from the second and third nested PCR was cloned into pGEM T-easy vector (Promega).

\section{Cloning of Fbos gene into E.coli by chemical transformation}

Three $\mu \mathrm{l}$ of PCR product was added to $1 \mu \mathrm{l}$ of T4 DNA ligase, $1 \mu$ l of pGEM $^{\circledast}$-T Easy Vector (50 ng) and $5 \mu \mathrm{l}$ of $2 \mathrm{X}$ Rapid Ligation Buffer for T4 ligase and incubated at room temperature for 1 hour. Twenty five $\mu 1$ of E. coli competent cells (Novagen) were thawed on ice. One $\mu 1$ of ligation mix was added directly to the cells with gently mixing by tapping. The competent cells with ligation mix were incubated on ice for 5 minutes. After heat shock for 30 seconds in a $42^{\circ} \mathrm{C}$ water bath, the tubes were put on ice for 2 minutes. Each transformation mix was spread on LB $1 \%$ ampicillin agar plate with $80 \mu \mathrm{l}$ of SOC medium and was incubated overnight at $37^{\circ} \mathrm{C}$. Single colonies were picked and cultured in $3 \mathrm{ml}$ liquid LB broth with $1 \%$ ampicillin by shaking overnight at $37^{\circ} \mathrm{C}$ on an orbital shaker at $250 \mathrm{rpm}$. Plasmid incorporated with PCR products, was isolated from the overnight bacterial culture following the manufacturer's protocol of QIAprep miniprep plasmid isolation kit (QIAGEN).

\section{Preparation of Digoxingenin (DIG) labeled DNA and RNA probe}

DIG-labeled DNA probe used for northern blot analysis was synthesized using a PCR DIG Probe Synthesis Kit (Roche diagnostics). A plasmid containing a 524 bp fragment of the Fbos gene was used as template. PCR reaction was performed following the conditions mentioned before, using gene specific primers and DIG labeled dNTP to introduce DIG label to PCR product.

DIG labeling RNA labeling kit was used to produce RNA probes for in vitro hybridization. The same plasmid that contains a 524 bp fragment of the Fbos gene was used to 
produce both sense and antisense probes through in vitro transcription. One $\mu \mathrm{g}$ of the plasmid was mixed with $5 \mu 1$ of $10 \mathrm{X}$ NE Buffer, $5 \mu \mathrm{l}$ of 10X BSA, $15 \mu \mathrm{l}$ of water and $5 \mu \mathrm{l}$ of SacI and ApalI separately. The restriction digestion mix was incubated in a PCR machine at $37^{\circ} \mathrm{C}$ overnight. The digested product and the cut out fragment were separated by electrophoresis on a $1 \%$ agarose gel. The digestion mix was extracted from gel following the standard protocol of QIAEX II Gel Extraction kit (QIAGEN). The bands containing digested DNA were sliced from the gel by removing excess agarose. Three volumes of buffer QX1 to one volume of agarose gel were applied to each sample to solubilize the agarose. Ten $\mu$ l of QIAEX II beads was added into each sample to bind the DNA by incubating at $50^{\circ} \mathrm{C}$ for 10 minutes and vortexing every 2 minutes to keep the beads suspension. Samples were centrifuged and the supernatant was discarded. The pellet was washed by QXII and PE buffer. After air dry, $20 \mu 1$ water was added to the pellet to elute the DNA from the beads. The final volume, about $18 \mu 1$ of purified digested plasmid DNA was collected. The in vitro transcription was conducted following the standard protocol of DIG RNA labeling Kit. The purified digested plasmid DNA was quantified using Nanodrop. The transcripts were created from $1 \mu \mathrm{g}$ linearized plasmid using either T7 (sense) or SP6 (antisense) RNA polymerases. SacI digested, linearized plasmid was mixed with $2 \mu 1$ of 10X NTP labeling mixture, $2 \mu 1$ of $10 X$ transcription buffer, $1 \mu 1$ of RNase inhibitor, $2 \mu 1$ of SP6 RNA polymerase and the remaining volume was made up with water to make a total volume of $20 \mu 1$ reaction mixture and was incubated at $37^{\circ} \mathrm{C}$ for 2 hours in a PCR machine. The reaction was stopped after two hours by adding $2 \mu$ l of $0.2 \mathrm{M}$ EDTA ( $\mathrm{pH} 8.0$ ). Two $\mu$ l of the RNA probe was using on electrophoresis checking for size and quantity. The sense probe was constructed in the same way described above, but using Apal I digested plasmid as template and T7 polymerase as in vitro transcription enzyme. 


\section{Northern Blot Analysis}

Three point seventy five $\mu \mathrm{g}$ of mRNA from oocyte was isolated and separated by electrophoresis on a $1 \%$ denaturing agarose gel containing $2.2 \mathrm{M}$ formaldehyde along with a RNA ladder (Promega) and then transferred to Hybond N+ nylon membrane (Amersham Biosciences, Pis) following capillary method. The purified mRNA was crosslinked onto the membrane by UV ray. DIG Easy Hyb solution (Roche) was used to pre-hybridizing the membrane for 1 hour. Ten $\mu 1$ of DIG DNA probe was added to fresh DIG Easy Hyb solution and hybridized with the membrane by incubating overnight at $68^{\circ} \mathrm{C}$. The membrane was washed under stringent conditions: 15 minutes $2 \mathrm{X}$ SSC with $0.1 \%$ SDS at room temperature for 2 times and 2 X 15 minutes with 0.1 X SSC with $0.1 \%$ SDS at $68^{\circ} \mathrm{C}$ for 2 times. The membrane was incubated in 5\% blocking solution (prepared from Blocking Reagent, Roche) for 30 minutes and alkaline phosphatase conjugated anti-DIG antibody (Roche) was added as 1: 10000 diluted, incubating for another 30 minutes. After washed in washing buffer twice, the hybridized probe was detected with the chemilumisescent substrate CSPD (Roche).

\section{Western Blot analysis}

The stages of egg and embryo samples were determined according to the diameter of the cell described previously. The quick frozen ovarian samples were chopped into $0.05 \mathrm{~g}$ and homogenized in $1 \mathrm{ml}$ T-per protein ext buffer with $10 \mu \mathrm{l}$ of Halt TM Protease inhibitor cocktail EDTA free (Thermo Scientific). After centrifuging at $15,000 \mathrm{~g}$ at $4^{\circ} \mathrm{C}$ for 30 minutes, the supernatant was collected and $2 \mu \mathrm{l}$ of samples were used to make 10 times dilution. Five $\mu l$ of each diluted sample was mixed with $250 \mu \mathrm{l}$ Coomassie Reagent (Thermo, Pierce) along with the standard control protein samples in a 96 well plate for quantifying the protein concentration following standard protocol of Coomassie Reagent. All the protein samples were diluted into 
same concentration of $5 \mathrm{mg}$ in $10 \mu \mathrm{l}$, and were dissolved in $10 \mu \mathrm{l}$ of $2 \mathrm{X}$ sample buffer (950 $\mu 1$ of Leammli sample buffer to which $50 \mu 1$ of $\beta$-mercaptoethanol was added). After being boiled in water bath at $95^{\circ} \mathrm{C}$ for 5 minutes, all the samples were immediately cool on ice for 10 minutes in $4^{\circ} \mathrm{C}$. Tris- $\mathrm{HCl}$ ready gel (BioRad) was loaded with protein samples and protein ladder. The electrophoresis was run in $1 \mathrm{X}$ Tris/Glysine/SDS running buffer for 2 hours. Proteins were then transferred onto a PVDF pre-wetted with methanol. The transfer reaction apparatus was kept in ice bath for 45 minutes with 100 volts in $1 \mathrm{X}$ transfer buffer (Tris/Glycine/SDS/methanol). The PVDF membrane was blocked for non-specific binding sites with blocking solution (non-fat dry milk in $1 \mathrm{X}$ TBS with $1 \%$ Tween 20). After blocking overnight at $4^{\circ} \mathrm{C}$ the membrance was incubated for 2 hours in primary antibody (rabbit raised polyclonal affinity purified antibody against 15 amino acid synthetic peptide of the novel Fbos protein ) (1:100 diluted in blocking buffer) and then was washed with TBS, Tween 20 solution (TBST) for 10 minutes for 3 times. The membrane was then incubated for 2 hours in secondary antibody (goat-antirabbit monoclonal antibody conjugated to horse radish peroxidase enzyme) and was washed 3 times by TBST. The SuperSignal West Pico Chemiluminescent substrate kit was used to detect the chemiluminescent protein signal.

\section{Preparation of paraffin sections for Rainbow Trout oocytes}

The paraformaldehyde-fixed oocyte samples from different developmental stages of vitellogenesis were embedded into a square model with $58^{\circ} \mathrm{C}$ melted paraffin. And the paraffin blocks containing tissue samples were sectioned $(5 \mu \mathrm{m})$, and mounted onto glass slides. All the slides were stored at $4^{\circ} \mathrm{C}$ no more than 2 weeks until use. 


\section{In situ Hybridization}

The Paraffin sections were de-paraffinized by immersion in Xylene 5 minutes for 3 times and then rehydrated through each descending ethanol concentration for 5 minutes: $100 \%$ for 3 times, $90 \%, 80 \%, 70 \%$ and $50 \%$ for 1 time each. After washing in PBS 10 minutes for 3 times, the sections were digested with proteinase $\mathrm{K}(2 \mu \mathrm{g} / \mathrm{ml})$ for 15 minutes at $37^{\circ} \mathrm{C}$ and acetylated in $0.25 \%(\mathrm{v} / \mathrm{v})$ acetic anhydride in $0,1 \mathrm{M}$ triethanolamine $(\mathrm{pH}$ 8.0) to break down the protein crosslink generated by fixation. The slides were washed in 4 X SSC 2 times for 10 minutes each and were incubated in $50 \%(\mathrm{v} / \mathrm{v})$ deionized formamide in $2 \mathrm{X} \mathrm{SSC}$ at $42^{\circ} \mathrm{C}$ for 30 minutes. About $100 \mu \mathrm{l}$ of ready-to-use prehybridization solution (Biochain) was applied to each slide and incubated at $50^{\circ} \mathrm{C}$ for 4 hours in a plastic box with water soaked paper twoel to avoid evaporation. Hybridization solution was prepared by mixing with the RNA probe at $1 \%$ concentration (v/v) and was applied to slides incubated in the same humidified box at $45^{\circ} \mathrm{C}$ overnight. After hybridization, the slides were treated with RNase A $(20 \mu \mathrm{g} / \mathrm{ml})$ for 30 minutes at $37^{\circ} \mathrm{C}$ and washed 3 times with $0.1 \mathrm{X} \mathrm{SSC}$ at $42^{\circ} \mathrm{C}$ for 20 minutes each. Hybridized probes were detected with an alkaline phosphatase conjugated anti-DIG antibody (Roche Diagnostics) and alkaline phosphatase reaction was developed with NBT/BCIP (Roche Diagnostics).

\section{Immunohistochemistry}

To localize the protein expression of the novel Fbos gene, immunohistochemistry was performed. The paraffin slides were de-paraffinized and rehydrated following the same pattern of in situ hybridization. After washed in ultrapure water for 5 minutes, the slides were incubated in $0.3 \% \mathrm{H}_{2} \mathrm{O}_{2}$ : Methanol to quench the endogenous peroxidase activity and were washed with PBS for 20 minutes. The Pierce ABC peroxidase staining kit and Metal enhanced DAB substrate kit were used to detect and visualize the protein signal. Blocking buffer (10 ml PBS, 3 drops of blocking serum from $\mathrm{ABC}$ kit and 1\% BSA) were applied to slides, which were incubated for 20 
minutes in a humidified chamber. Primary antibody was diluted with blocking buffer (1:1000) and the slides were treated with antibody solution by incubating for 30 minutes. After washing in PBS for 10 minutes, the slides were incubated for 30 minutes with biotinylated Secondary antibody (Pierce $\mathrm{ABC}$ kit) and were washed again with $\mathrm{PBS}$ for 10 minutes. The $\mathrm{ABC}$ reagent was applied to the slides, which were incubated for 30 minutes and washed with PBS. After removing the excess buffer, Metal enhanced DAB substrate working solution was added to the slides until the desire brownish color showed on the slides.

\section{Real Time Polymerase Chain Reaction}

The expression of Fbos mRNA during oogenesis and early embryonic development was quantified using real time PCR. Total RNA from different developmental stages of oocytes and embryos was isolated and was subjected to DNAse treatment. The DNAse-treated total RNA from each stage oocyte or embryos was converted to cDNA using Superscript III reverse transcriptase (Invitrogen, CA). Real time PCR primers for Fbos gene and the endogenous control gene (Histone H2A primer sequences in table 1.) were designed based on the corresponding cDNA sequences (rainbow trout histone H2A: TC85036 in TIGR database) using Primer3 software ( duplicate on a Bio-Rad iCycler iQ Real-Time PCR Detection System using $\mathrm{iQ}^{\mathrm{TM}} \mathrm{SYBR}^{\circledR}$ Green Supermix (Bio-Rad, Hercules, CA) in 25- $\mu$ l reaction volumes containing each primer at $300 \mathrm{nM}$ and a cDNA generated from $0.1 \mu \mathrm{g}$ of total RNA. Standard curves for the Fbos gene were constructed using 10-fold serial dilutions of the corresponding plasmid; as for histone $2 \mathrm{~A}$, standard curves were constructed using 10 -fold serial dilutions of a fragment of histone $2 \mathrm{~A}$ cDNA. Standard curves for both Fbos and endogenous control were run on the same plate with the samples. Threshold lines were adjusted to intersect amplification lines in the linear portion of 
the amplification curve and cycles to threshold $(\mathrm{Ct})$ were recorded. For each sample, the quantities of the Fbos mRNA and the control gene histone 2A mRNA were determined from the appropriate standard curve. To obtain a normalized value of Fbos gene, the quantity of Fbos mRNA was divided by the quantity of the histone 2A. One way analysis of variance (ANOVA) was performed on normalized gene expression values using a statistical analysis package, SigmaStat version 3.11 (Aspire Software International, Leesburg, VA). The expression of Fbos mRNA was then demonstrated as relative fold changes.

\section{Yeast Two Hybridization}

The matchmaker two-hybrid system (Clontech Laboratories) was used in the study. As a host yeast strain, AH109 competent cells were used. Yeast handling and transformation were carried out according to the manufacturer's instructions. Vector pGBT7 was used to generate fusion bait protein in which the complete ORF region of Fbos was located downstream of a GAL4 binding domain. The $1.5 \mathrm{~kb}$ PCR product of complete ORF region of Fbos gene was ligated with pGBKT7 into specific cutting sites of NdeI and SalI. The first strand cDNA of oocyte cDNA library was synthesized following standard protocol of the SMART (Switching Mechanism at 5' end of RNA transcript) technology. Linearized vector pGADT7 was used to generate fusion prey protein for Fbos bait protein. After amplification by PCR all the cDNAs were cotransformed into AH109 competent cells along with pGADT7 and pGBKT7 with Fbos insert. Yeast cells were plated on synthetic dropout selection medium lacking histidine, leucine and tryptophan (Med dropout plate)

(SD/-his/-leu/-try) and incubated at $30^{\circ} \mathrm{C}$ for 3 days. Single colonies $(>2 \mathrm{~mm}$ ) were selected and streaked on fresh Med dropout plates. Plasmid was isolated from $5 \mathrm{ml}$ liquid culture of Med dropout medium from single colonies and was transformed into E.coli competent cells 
using ampicillin as antibiotic to select only pGADT7. The plasmids then were sequenced and a GenBank database search was performed through the NCBI using BlastX.

\section{A $\beta$-galactosidase assay}

Yeast $\beta$-galactosidase liquid assay was performed using CPRG (cholorophenol red- $\beta$ D-galacto-pyranoside) according to the method described in the manual of the MATCHMAKER two-hybrid system (Clontech Laboratories). The $\beta$-galactosidase units were calculated using the

following formula: $\beta$-galactosidase units $=1000 \times \mathrm{OD}_{578} /\left(\mathrm{t} \times \mathrm{V} \times \mathrm{OD}_{600}\right)$. Where $\mathrm{OD}_{578}$ is the absorbance of chlorophenol red and $\mathrm{OD}_{600}$ is the cell density at the start point; $\mathrm{t}$ is elapsed time (in minute) of incubation; $\mathrm{V}$ is $0.1 \mathrm{x}$ concentration factor. 1 unit of $\beta$-galactosidase was defined as the amount that hydrolyzed $1 \mu \mathrm{mol}$ of CPRG to chlorophenol and D-galactose per minute per cell. 


\section{Results}

\section{Cloning of the novel F-box protein}

Analysis of ESTs from a rainbow trout oocyte cDNA library indentified many novel sequences that did not show significant homologies to sequences of any known genes or ESTs deposited in the GenBank database. Six novel ESTs that were present in the oocyte library but absent in libraries from other tissues were selected for analysis of expression patterns in multiple tissues by RT-PCR. One of them, TC86806, appeared to be oocyte-specific and not in other tissues (Figure 3). To determine the transcript size of the novel gene and verify whether it has alternative splicing variants, Northern blot analysis was performed. It showed in Figure 4 that this novel gene has a single transcript corresponding to a size of $2.1 \mathrm{~kb}$. Publicly available EST database TIGR was used to analysis the sequence, similar EST BX 31679 was found to have an extra 15 bp sequence on 5' end. 5' RACE was performed to obtain the $1996 \mathrm{bp}$ full length of the cDNA.

\section{Sequence Analysis of Fbos gene}

Analysis of the novel cDNA sequence showed that it contained a 14 bp 5'untranslated region (5'-UTR), an open reading frame (ORF) of 1545 bp and 3' untranslated region (3'-UTR) of 438 bp (Figure 4). The ORF codes for a protein of 514 amino acids. Searching the BlastX database revealed that this gene contained an F-box domain. This domain was located at aminoterminal from residue 39 to residue 86 and this novel protein was not predicted to have any common secondary motifs such as LRR or WD regions which indicated that the novel protein is an F-box only protein. Therefore we named this novel gene as Fbos (F-box oocyte-specific). 


\section{Quantitative analysis of Fbos mRNA expression during oogenesis and early embryonic development}

To characterize the expression of Fbos, real time PCR was performed using gene specific primers in different developmental stages of rainbow trout oocyte. The classification of developmental stages of the ovary and oocyte was based on the study by Tyler et al. (1994). During oogenesis, intense Fbos expression was observed in early pre-vitellogenesis, and the transcription appeared to decrease dramatically in late pre-vitellogenesis and to decrease to barely detectable in early embryonic development at day 0, day 4 and day 7 after fertilization (Figure 6). This expression pattern indicated a potential role of Fbos during early previtellogenesis stage during which the oocyte increase in size with the formation of chorion vitelline envelope (Tyler and Sumpter 1996).

\section{Protein expression analysis of Fbos in different stages of oogenesis}

To investigate the expression of Fbos protein, a polyclonal antibody was raised in rabbits against the rainbow trout Fbos amino acids from residue 263 to 277 (Figure 5). Protein samples, isolated from late and mid-vitellogenesis oocytes, ovulated oocytes and earlyprevitellogenesis oocytes, were used in western blot. As showen in Figure 7, the expression of Fbos protein was dramatically higher in early-previtellogenesis and was not detectable in other samples, which agreed with the real time PCR result.

\section{Localization of Fbos $m R N A$ and protein in different stages of oocytes}

In situ hybridization on rainbow trout ovarian sections showed that Fbos mRNA appeared to be confined to the small, early-vitellgenesis of oocytes (arrows in Figure 8). No significant difference was detected in oocyte nucleus. There appeared to be fewer or no detectable signals in the large oocytes which were at later stages (arrowheads in Figure 8). Immunohistochemistry showed similar results with in situ hybridization (Figure 9). In early 
stages of oocytes, the protein signals were greater than in late stages (arrowheads). Both the mRNA and protein localization results agreeed with the real time PCR result.

\section{Identification of Fbos binding proteins}

The complete coding region of Fbos was cloned into GAL-4 DNA binding domain to generate a bait protein. A total of 18 colonies were identified by selecting through high stringency plate (SD/-ade/-his/-leu/-trp). These colonies also showed LacZ activity in $\beta$ galactosidase colony-lift filter assay (data not shown). Plasmids of 18 colonies were collected and transformed into E. coli. Seven of them were rescued from the bacterial culture and were subjected to DNA sequence analysis using BlastX database. To further confirm the interaction of these proteins, two selective plasmids harboring sequences of tissue inhibitor of metalloproteinase and adenylate kinase 2 were re-cotransformed with Fbos BD plasmid into yeast competent cell. Both of them were grown in three dropout media and a single colony was selected to be tested using $\beta$-galactosidase assay.

To confirm the binding affinity of the selective protein from positive colonies of yeast two hybridization system, $\beta$-galactosidase assay was performed using CPRG. Figure 10 showed that the $\beta$-galactosidase activity in yeast cells harboring tissue inhibitor of metalloproteinase and adenylate kinase 2 was significantly greater than in the negative control. 


\section{Discussion}

F-box protein has been studied as a core subunit of ubiquitin ligase in several species. In this study, we identified and characterized a novel gene specifically expressed in rainbow trout oocytes. Using the NCBI database, we identified and cloned this novel gene from a rainbow trout oocyte cDNA library, and an F-box domain was found by Pfam on amino-terminal. Protein sequence analysis using EMBL database showed that apart from the F-box domain, there was a fas-associated death domain located from residue 89 to 183. Fas proteins have been implicated in cellular activation differentiation and proliferation and most importantly apoptotic processes. BlastX showed that Fbos protein was similar to a hypothetical protein of zebrafish (NP_001037797.1) which shared 81\% identity with the Fbos protein. However, the cDNA sequence of Fbos gene did not have any homology with other known genes in GenBank.

F-box domain and F-box protein family are named after human cyclin F which was found in 1994 by Bai et al.. It is a conserved domain that usually has 50 amino acids. The F-box domain of Fbos was located from amino acid 39 to amino acid 86, which contains 47 amino acids. In different species, F-box protein is found both in cytoplasm and nucleus which was also shown in this study by both in situ hybridization and immunohistochemistry. There was no significant difference between cytoplasm and nucleus (Kipreos and Pagano 2000). There are more than 326 predicted F-box sequences in C. elegans, 22 in Drosophila, 68 in human beings; it also has been found in plants such as rice and Arabidopsis (Durfee et al. 2003; Gomi et al. 2004) and recently reported in mice ovary as an oocyte-specific gene (De La Chesnaye et al. 2008).

In rainbow trout, ubiquitin-proteasome pathway has captured increasing attention in the field of muscle atrophy (Seiliez et al. 2008). Ubiquitin-proteasome pathway of intracellular protein degradation governs the abundance of important regulatory proteins (Craig and Tyers 
1999). Several F-box proteins were found to have active function in this field such as atrogin-1 and MuRfl(Seiliez et al. 2008). However, to our knowledge, this study is the first report to an oocyte-specific F-box gene in fish species.

Sumoylation is another post-translational protein modification system. It can change and regulate the function of a protein by attaching the small protein sumo to the substrate (Johnson 2004). Sumoylation can affect a wild range of proteins. Proteins that can be sumoylated contain one or multiple sumo sites. It is reported that lacking one of the SUMO protein $U b c 9$ will lead to early embryonic death in mice (E Meulmeester 2008). In this study, using the online program GPS sumo site searcher, we found that there was a sumo site located on lysine residue 190, which indicated that the expression of the novel protein of Fbos might be regulated by sumoylation.

F-box proteins are the core subunit of SCF complex in ubiquitin ligase. F-box proteins with their specific substrate proteins are involved in a wide range of ubiquitin-mediated proteolysis in various cellular processes. To identify the substrate of F-box protein is very important to the function study of this protein family. Yeast two hybridization was used to isolate the proteins that bind with Fbos. Plasmids containing interaction proteins from four positive yeast colonies were isolated and sequenced (Table 2). Two of them had partial sequences of adenylate kinase, which catalyses the interconversion of ATP. Another two colonies contained the partial sequence of $Z P 2$ (zona protein 2), an important structural protein, which is expressed as early as the formation of primary follicles in rainbow trout. Histone H3 is a DNA-binding protein that mediates the folding of DNA into chromatin. Various posttranslational modifications of histones regulate processes such as transcription, replication and repair of DNA, especially, during early embryonic development in the mouse, the methylation of certain arginine residues 
of histone $\mathrm{H} 3$ directly contributed to the transition from blastomeres to pluripotent cells of the inner cell mass (Torres-Padilla et al. 2007). Ribosomal proteins S, L and P type are groups of important catalytic proteins which are essential for translation. It was found that the transcripts number of ribosomal protein L36 was relatively high in zebrafish ovarian follicles. Especially during germinal vesicle breakdown (GVBD), there was a greater expression of the mRNA of ribosomal protein L36, which indicated the potential requirement of the transcripts of ribosomal protein L36 in oocyte maturation. The identification of ribosomal protein L36 as a protein substrate of Fbos might shed light on the functional study of Fbos gene during oogenesis in rainbow trout.

Two single colonies respectively containing proteins of tissue inhibitor of metalloproteinase (TIMP) and adenylate kinase 2 were selected with the confirmed interaction and further study of $\beta$-galactosidase activity assay was performed to quantify the intensity of the interaction between Fbos and these two proteins (Figure 10). TIMP is known to play an important role in regulating the activity of matrix metalloproteinases (MMP) which are the key metal-dependent enzymes in the extracellular matrix (ECM) remodeling of follicular tissue. The MMPs are in charge of degrading proteinaceous components of the ECM and the ratio between TIMP and MMP determines the extent of ECM remodeling. If the ratio is in favor of MMP activity then it leads to ECM degradation, however, a TIMP activity favored ratio will inhibit ECM degradation and enhance its deposition (McIntush and Smith 1998). TIMPs are highly abundant in reproductive tissues; besides being involved in ECM remodeling, TIMPs are also known to stimulate cell proliferation, early embryonic development and progesterone secretion. The expression of TIMP has been detected in unfertilized oocytes, zygotes, cleavage stage embryos and blastocysts (Brenner et al. 1989). 
In summary, we have cloned a novel gene related to the ubiquitin ligase E3 in rainbow trout and proved that it is an oocyte-specific gene. It is abundantly expressed in earlyprevitellogenic oocyte and barely detectable in early embryonic stage. The protein contains a conserved F-box domain. Based on this, the Fbos protein might share similar functions as other F-box genes found in rainbow trout muscle, which is a key subunits in ubiquitin ligase E3. The unique tissue and stage expression pattern of Fbos indicates that in has a distinct and important role the previtellogenic stage of in rainbow trout oogenesis. 


\section{Tables and Figures}

Table 1. All the primers that we used in this experiment are listed in table 1

\begin{tabular}{|c|c|c|c|}
\hline PCR method & Primer name & Primer sequences & Product Size \\
\hline \multirow[t]{2}{*}{ Regular PCR } & TC86806-F852 & GACATCAGATACCTGGCCTCA & \multirow{2}{*}{$523 \mathrm{bp}$} \\
\hline & TC86806-R1375 & TGGGAGATCTTGGTGTCAAAC & \\
\hline \multirow{4}{*}{ 5'RACE } & F-Box-5end & GCAGGTGGCAAATATGGCAC & \\
\hline & F-Box-SP1-50 & GCGAGAACTGTCCCTGCAAC & \\
\hline & F-Box-SP2-105 & CGTCCATGTGTGTCCTCACTT & \\
\hline & F-Box-SP3-136 & CGTCACTTAAGTCTAGTATCCC & \\
\hline \multirow{4}{*}{ Real Time PCR } & F-Box-1436 Forward & CTCTACCTGGAGGCAGTGAAA & \multirow{2}{*}{$131 b p$} \\
\hline & F-Box-1567 Reverse & GAGTGCTCAATCTGCGTTAGC & \\
\hline & His2AForward & TCCCCAAGAAGACTGAGAAGG & \multirow{2}{*}{$114 b p$} \\
\hline & His2AReverse & TTTGTTGAGCTAGGTGGTTGG & \\
\hline \multirow{2}{*}{$\begin{array}{l}\text { Yeast Two } \\
\text { Hybridization }\end{array}$} & Fbox-Y2Forward & ATGTCGACTTATGGCACTTCGT & \multirow{2}{*}{$2016 b p$} \\
\hline & Fbox-Y2Reverse & ATATGTCGACCTAGCTGAC & \\
\hline
\end{tabular}

Table 1 Primers 
Table 2. Genes indentified by yeast two hybridization system

\begin{tabular}{lr} 
Names of homologous proteins & Accession number \\
\hline Histone H3.3 & r_trout|TC134429 \\
Tissue inhibitor of metalloproteinase 2 & r_trout|TC162649 \\
Adenylate kinase 2 & r_trout|TC144315 \\
Ribosomal protein L36 & r_trout|TC142228 \\
Oocyte protease inhibitor 1 & r_trout|TC162286 \\
Zona pellucida protein 2 & r_trout|TC138971 \\
\hline
\end{tabular}

\section{Table 2 Accession number}

The names of the homologous proteins and their accession numbers are listed in table 2 . Two colonies are related to adenylate kinase 2 and zona pellucids protein 2 respectively, but for adenylate kinase 2, those two colonies are homologous to the same TC sequence. 
Figure 1.

\begin{tabular}{|c|c|}
\hline -TRCP1) & 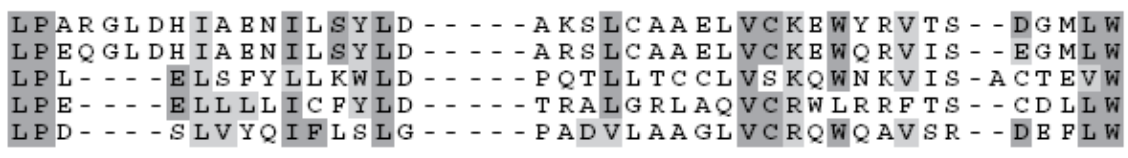 \\
\hline $\begin{array}{l}a \\
0 \\
0\end{array}$ & 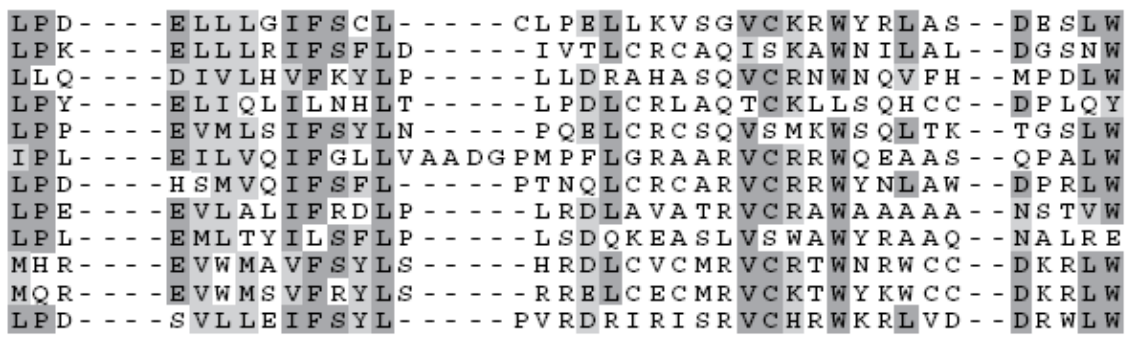 \\
\hline $\begin{array}{l}\text { a } \\
\text { b } \\
\\
\\
0 \\
1 \\
2 \\
3 \\
4 \\
5 \\
6 \\
7 \\
8 \\
9 \\
9\end{array}$ & 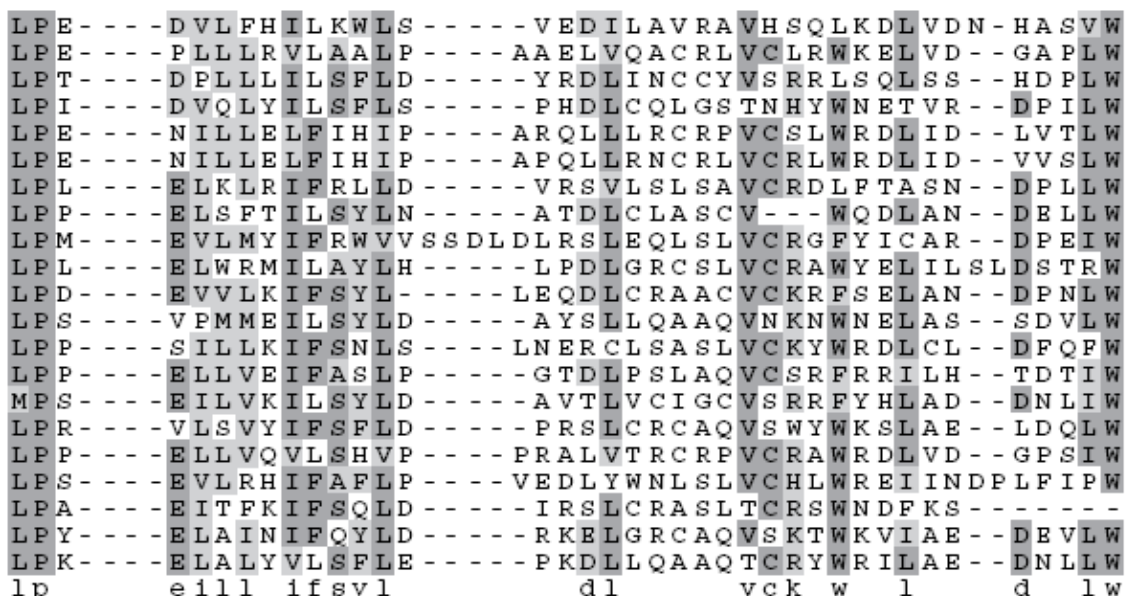 \\
\hline & 政 \\
\hline
\end{tabular}

\section{Figure 1 Consensus sequences of F-box proteins}

Thirty eight sequences reported in the paper of Cenciarelli et al. were complied and aligned using Clustal 1.7. Consensus amino acids were showed on bottom. Dark gray, identical residues; light gray, similar residues; h, human; m, mouse 
Figure 2.

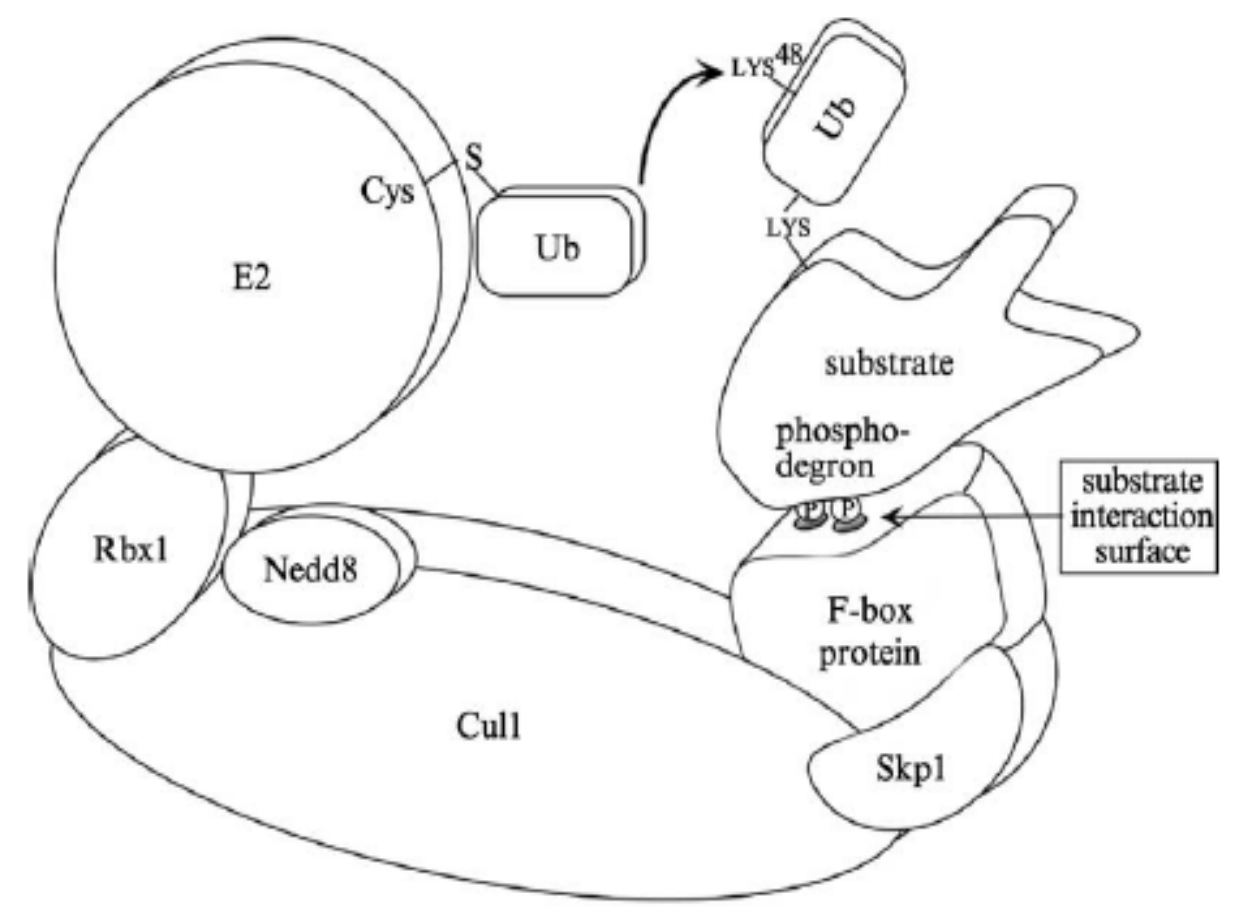

\section{Figure 2 SCF complex}

Cullin is a scaffold protein, which binds with ubiquitin conjugating enzyme E2, and a ring-finger protein Rbx1 to form the core E3 ubiquitin ligase which activates E2. Also Cullin is stabilized by Nedd8. Binding with cullin on its amino-terminal, Skp1 also bind with F-box motif of an F-box protein, which interacts with the phosphorylated protein target. (Jianping Jin 2005) 
Figure 3.

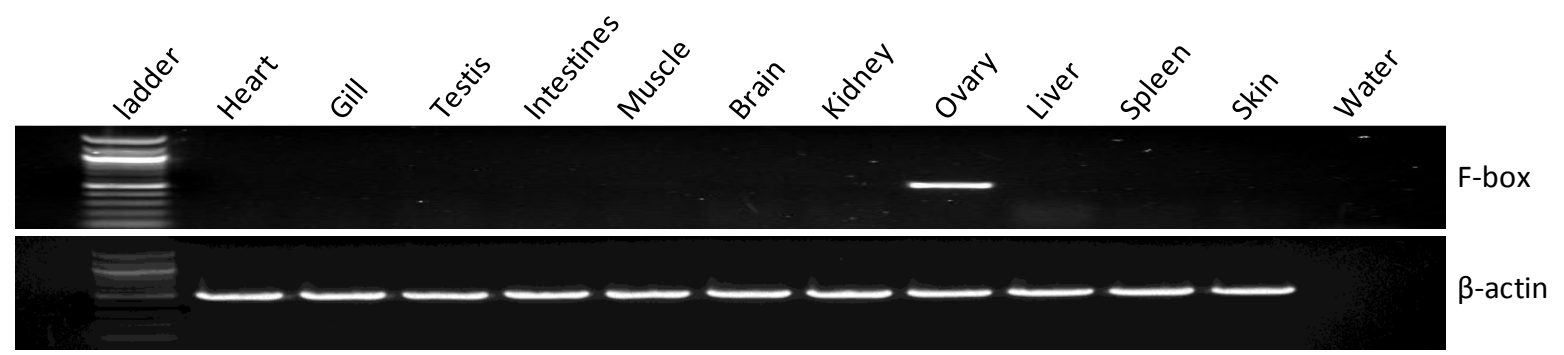

Figure 3 RT-PCR analysis of tissue distribution of Fbos

RT-PCR using 10 somatic tissues and ovary was performed and trout $\beta$-actin was used as a control for RNA quantity. It is showed that Fbos gene is only expressed in rainbow trout ovary. Water is used as negative control. 
Figure 4.

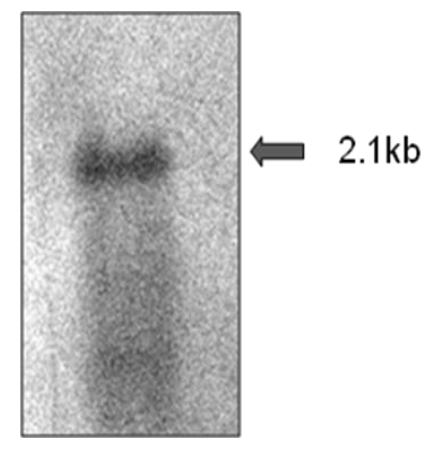

Figure 4 Northern blotting analysis of Fbos mRNA from early vitellogenic oocytes

mRNA form early previtellogenesis oocytes was used in the analysis and the blot was hybridized with a DIG-labeled anti-sense RNA probe generated by in vitro transcription of a 524 bp Fbos fragment. Northern blot showed that the novel Fbos gene has a $2.1 \mathrm{~kb}$ single transcript. 
Figure 5 .

1 acaggtggcaatêtGgCACTTCGTGAGGATAGTTCGGAGGATGAGTTGCAGGGACAGTTCTCGCTTTTA 70 $\begin{array}{llllllllllllllllllll} & A & L & R & E & D & S & S & E & D & E & L & Q & G & Q & F & S & L & L\end{array}$

71 TCCGCGACTTCATtCGAGgTCACAGATGAAAGTGAGGACACACATGGACGCTCCGAAACGgGGATACTAG 140 $\begin{array}{llllllllllllllllllllllll}S & A & T & S & F & E & V & T & D & E & S & E & D & T & H & G & R & S & E & T & G & I & L\end{array}$

141 AстTAAgTGACGAAGTCTTTATTCTCATCCTACGACGGCTGGATCCCACGTCTCTCTTGAGAGTTGGGAG 210 $\begin{array}{lllllllllllllllllllllllllllllllllll}D & L & S & D & E & V & F & I & L & I & L & R & R & L & D & P & T & S & L & L & R & V & G & S\end{array}$

211 CACCTGCCGAACCCTGTTTCGAGTTTGTTCCTGCAACTCACTGTGGACAAAACACTTCCAGACCTCATTT 280 $\begin{array}{lllllllllllllllllllllllll}\mathrm{T} & \mathrm{C} & \mathrm{R} & \mathrm{T} & \mathrm{L} & \mathrm{F} & \mathrm{R} & \mathrm{V} & \mathrm{C} & \mathrm{S} & \mathrm{C} & \mathrm{N} & \mathrm{S} & \mathrm{L} & \mathrm{W} & \mathrm{T} & \mathrm{K} & \mathrm{H} & \mathrm{F} & \mathrm{Q} & \mathrm{T} & \mathrm{S} & \mathrm{F}\end{array}$

281 GGAGTCCCGTTTGCCACCGCCGCCTGCTCCATCTCTGCCAAGAGTGCCTTCCGTTTGGTCTTCATGTGGC 350 $\begin{array}{llllllllllllllllllllllllllllllll}G & V & P & F & A & T & A & A & C & S & I & S & A & K & S & A & F & R & L & V & F & M & W\end{array}$

351 GAACTCTCTTTAGAAACCTGCATTGTAACCGGTCTCTTCAGGAGAAGCTCTTTGCAGAGATCCCATTCCC 420

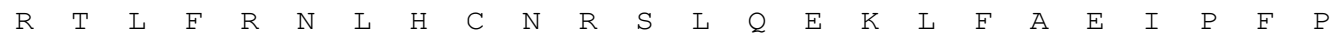

421 ACCACACAAGTACTGGgTCCAGTGGCTGGTTCTGGAAGAGACTGTTCCTCTGCCCTCCGTGAGACTGCCT 490 $\begin{array}{llllllllllllllllllllllllllll}P & H & K & Y & W & V & Q & W & L & V & L & E & E & T & V & P & L & P & S & V & R & L & P\end{array}$

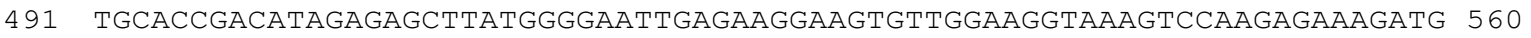
$\begin{array}{llllllllllllllllllllllllllll}C & T & D & I & E & S & L & W & G & I & E & K & E & V & L & E & G & K & V & Q & E & K & D\end{array}$

561 AgGATGAgGgCAgAATGCTGAAgTtCGAATGGAAgGAGCTGTATGCCTTGGCCCTTGAGCACCATGGAAG 630 $\begin{array}{llllllllllllllllllllllllllllll}E & D & E & G & R & M & L & K & F & E & W & K & E & L & Y & A & L & A & L & E & H & H & G & S\end{array}$

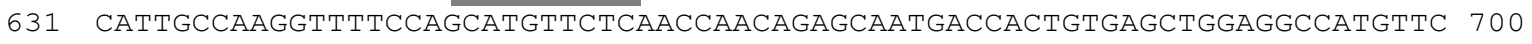
$\begin{array}{llllllllllllllllllllllllllllllllll}I & A & K & V & F & Q & H & V & L & N & Q & Q & S & N & D & H & C & E & L & E & A & M & F\end{array}$

701 AgtCAgtACAgCCAGTGTCGGTTCCAGTGGCTCTTCACCTACTGGTTGTTCCGCCAGCCAGCGCCCTTCG 770 $\begin{array}{llllllllllllllllllllllllllllllllll}S & Q & Y & S & Q & C & R & F & Q & W & L & F & T & Y & W & L & F & R & Q & P & A & P & F\end{array}$

771 ACAGGCAGCTCAgGGCCATCTACCTGCAGTGGCAGAAGCACAGCAAGAGGAAGGTGGTGTCCTGGGGAGG 840 \begin{tabular}{lllllllllllllllllllllllll}
$\mathrm{D}$ & $\mathrm{R}$ & $\mathrm{Q}$ & $\mathrm{L}$ & $\mathrm{R}$ & $\mathrm{A}$ & $\mathrm{I}$ & $\mathrm{Y}$ & $\mathrm{L}$ & $\mathrm{Q}$ & $\mathrm{W}$ & $\mathrm{Q}$ & $\mathrm{K}$ & $\mathrm{H}$ & $\mathrm{S}$ & $\mathrm{K}$ & $\mathrm{R}$ & $\mathrm{K}$ & $\mathrm{V}$ & $\mathrm{V}$ & $\mathrm{S}$ & $\mathrm{W}$ & $\mathrm{G}$ & $\mathrm{G}$ \\
\hline
\end{tabular}

841 CACGTTGTGTGACATCAgAtACCTGgCCTCATtACATCACATCACTTCCGACTACTGGCGGGGCAAGCTG 910

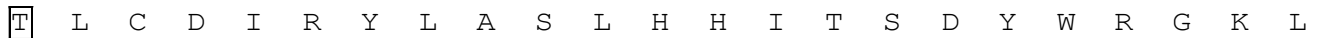

911 GCCCAGGgTGACGAGACTGTGGGAATtCAGACAGTGGAAAACTATTTCTCCATGTGCAAATCCCTGGTGG 980 $\begin{array}{llllllllllllllllllllllll}A & Q & G & D & E & T & V & G & I & Q & T & V & E & N & Y & F & S & M & C & K & S & L & V\end{array}$

981 CCTGGATtTtAgGGCGTGACTGGGGCAGATTGAAAAGCAAAAAGgTGTACGAGGACACGCTGGAGGGTGT 1050 $\begin{array}{llllllllllllllllllllllll}A & W & I & L & G & R & D & W & G & R & L & K & S & K & K & V & Y & E & D & T & L & E & G & V\end{array}$

1051 GTACCTGCTGCTGAGGAGGGAGATGCAGGAGACCCTGGTGGAGCACGAGAGGTTCTGGCAGGTGGCCAAG 1120 $\begin{array}{llllllllllllllllllllllll} & \mathrm{L} & \mathrm{L} & \mathrm{L} & \mathrm{R} & \mathrm{R} & \mathrm{E} & \mathrm{M} & \mathrm{Q} & \mathrm{E} & \mathrm{T} & \mathrm{L} & \mathrm{V} & \mathrm{E} & \mathrm{H} & \mathrm{E} & \mathrm{R} & \mathrm{F} & \mathrm{W} & \mathrm{Q} & \mathrm{V} & \mathrm{A} & \mathrm{K}\end{array}$

1121 GTCCAGATGACCCGAGTGTGTACCCTGGAGGAGACTGCTGTAAACTATGTCAACTGGAAGATGATTGAAA 1190 $\begin{array}{llllllllllllllllllllllllll}V & Q & M & T & R & V & C & T & L & E & E & T & A & V & N & Y & V & N & W & K & M & I & E\end{array}$

1191 CACTGCCCTACTACAAGCTGTACTTGGTGTCAGGCAACATGGTTTACCTAGACCACGTGCAGGGCTTCCT 1260 $\begin{array}{lllllllllllllllllllllllllllll} & \mathrm{L} & \mathrm{P} & \mathrm{Y} & \mathrm{Y} & \mathrm{K} & \mathrm{L} & \mathrm{Y} & \mathrm{L} & \mathrm{V} & \mathrm{S} & \mathrm{G} & \mathrm{N} & \mathrm{M} & \mathrm{V} & \mathrm{Y} & \mathrm{L} & \mathrm{D} & \mathrm{H} & \mathrm{V} & \mathrm{Q} & \mathrm{G} & \mathrm{F} & \mathrm{L}\end{array}$

1261 CCACAGGAAGAGGCTGGTCCATGACTGGTTCTTCATGAAGGAGAACACCTGGGTCAGACAGCTGCTGCCT 1330 $\begin{array}{lllllllllllllllllllllllll}\mathrm{H} & \mathrm{R} & \mathrm{K} & \mathrm{R} & \mathrm{L} & \mathrm{V} & \mathrm{H} & \mathrm{D} & \mathrm{W} & \mathrm{F} & \mathrm{F} & \mathrm{M} & \mathrm{K} & \mathrm{E} & \mathrm{N} & \mathrm{T} & \mathrm{W} & \mathrm{V} & \mathrm{R} & \mathrm{Q} & \mathrm{L} & \mathrm{L} & \mathrm{P}\end{array}$

1331 GGGGACCTCTACCCTCTGCTGGAGTTTGACACCAAGATCTCCCAAGACAGCCTGCATGGAGACTCCATGC 1400 $\begin{array}{llllllllllllllllllllll}G & D & L & Y & P & L & L & E & F & D & T & K & I & S & Q & D & S & L & H & G & D & S\end{array}$

1401 CAGCCCAGCTGAGCAGGGTGATGTGGCTGTACCTCCACTCTGGACAGACACTCTACCTGGAGGCAGTGAA 1470 $\begin{array}{llllllllllllllllllllllll}P & A & Q & L & S & R & V & M & W & L & Y & L & H & S & G & Q & T & L & Y & L & E & A & V & K\end{array}$

1471 AgGCCTGGTGCTGCAGTGTGCTCAGGCCAGTCTGGGACACTTCTGCAGCCTCTCCCCTGGTGCCTCTATT 1540 $\begin{array}{lllllllllllllllllllllll}G & L & V & L & Q & C & A & Q & A & S & L & G & H & F & C & S & L & S & P & G & A & S & I\end{array}$

1541 CAGCCCCATGTCAGC $\underline{\mathbf{T A G}} \mathbf{c}$ ggctaacgcagattgagcactctgttttagagcctctacgagatgtacag 1610 Q $\quad$ P $\quad \mathrm{H} \quad \mathrm{V} \quad \mathrm{S}$

1611 tcccatgttgttgttctttactggatccagtgtccagtgcttttatcactttttactgtattttatcacc 1680 1681 actcagattttagctggcgagctggaattaatagattttaaatgaatttttaa acttgaatctttatcaa 1750

1751 tagttaatgaaatgtaggctattgatgtacattgtagaaaccgtgtttgctgtcatgtaattactctaca 1820

1821 gccaacatttggggcaagctattgaagtgatgacattgctcaatcattctcaatggtaaatgtgtcata 1890

1891 ttcaaggctaacaattcttggccaattaacaggctagaaacttaacagtgctgggttgctgtataatga 1960

1961 ataacaactctgacaacttaaaaaaaaaaaaa 1996

\section{Figure 5 Full length cDNA sequence of Fbos}

Analysis of the novel cDNA sequence showed that it contains a 13 bp 5 'untranslated region (5'-UTR), an open reading frame (ORF) of 1545 bp and 3' untranslated region (3'-UTR) of $438 \mathrm{bp}$. Bold letters indicated start and stop codons, grey shading indicated F-box domain, dark grey shading indicated sumo site, amino acid sequence with box indicated the polypeptide sequence used to rise the anti-Fbos polyclonal antibody. 
Figure 6.

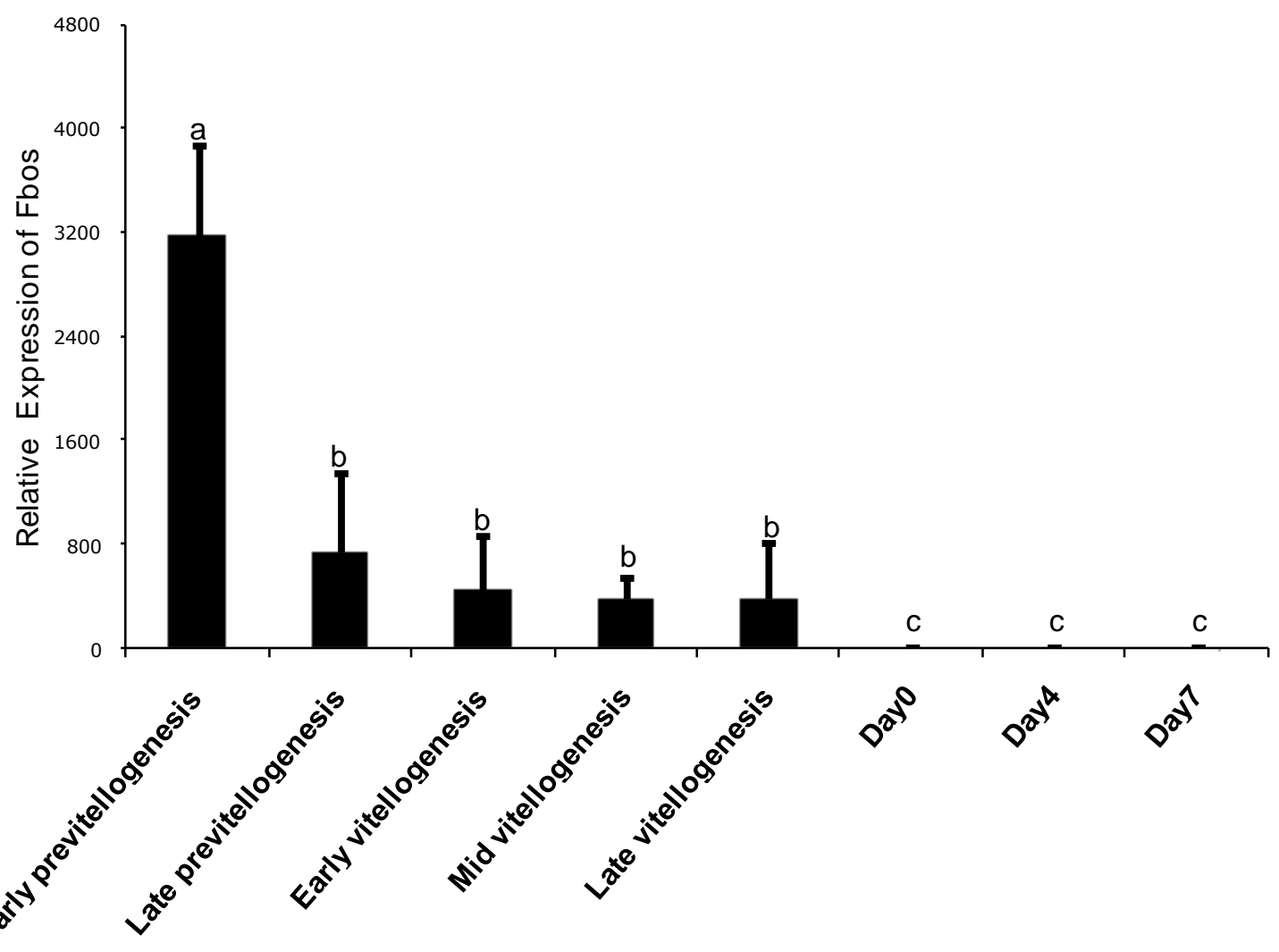

Figure 6 Real-Time PCR analysis of Fbos mRNA levels in different developmental stages of oocytes and early embryos

Real time PCR result indicated that Fbos mRNA is highly expressed in earlyprevitellogenic oocytes, and decreased dramatically in late pre-vitellogenesis and was undetectable in early embryonic development at day 0 , day 4 and day 7 after fertilization. The quantity of Fbos mRNA was normalized to trout histone H2A, The means of the mormalized gene expression values for each stage were calculated and showed as relative fold changes. Different letters $a, b, c$ indicate significant difference $(\mathrm{P}<0.05)$. 
Figure 7.

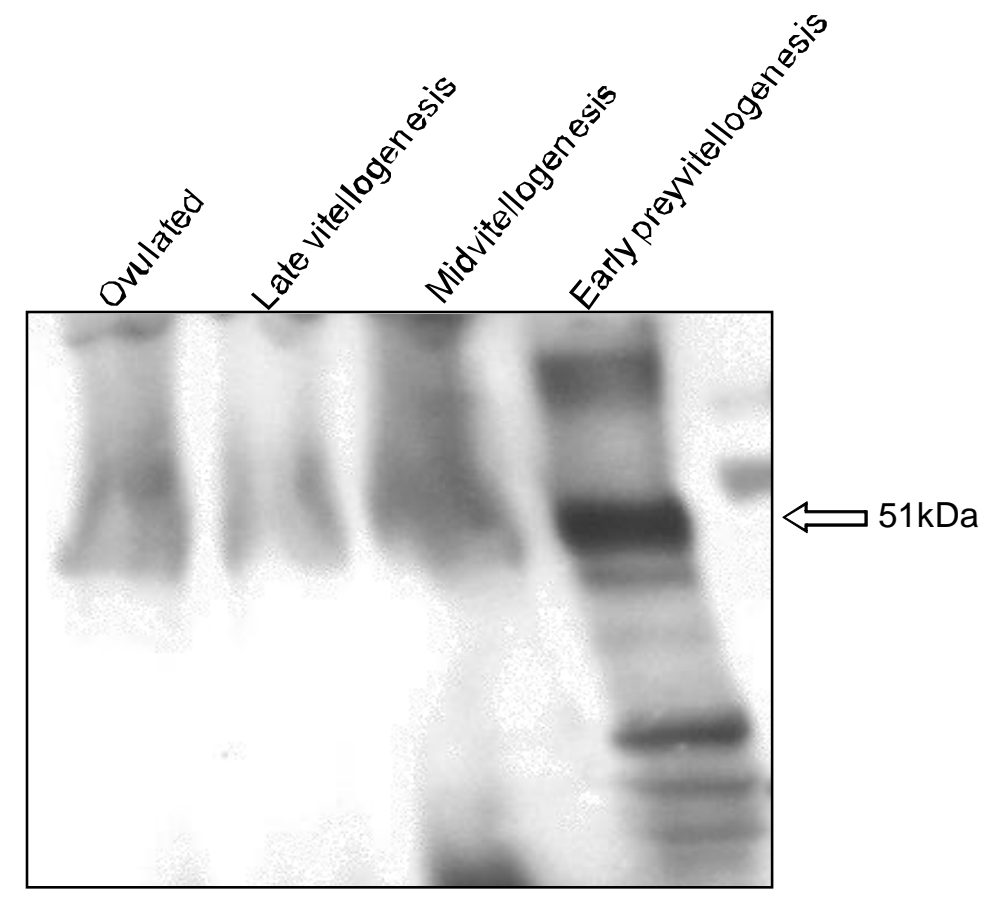

Figure 7 Western Blotting analysis of Fbos in different stages of oocytes

Western blot detection of Fbos protein in rainbow trout oocytes by using antibody generated against Fbos protein (polypeptide sequence showed in figure 5). In early previtellogenic stage, Fbos protein has the strongest expression. 
Figure 8.

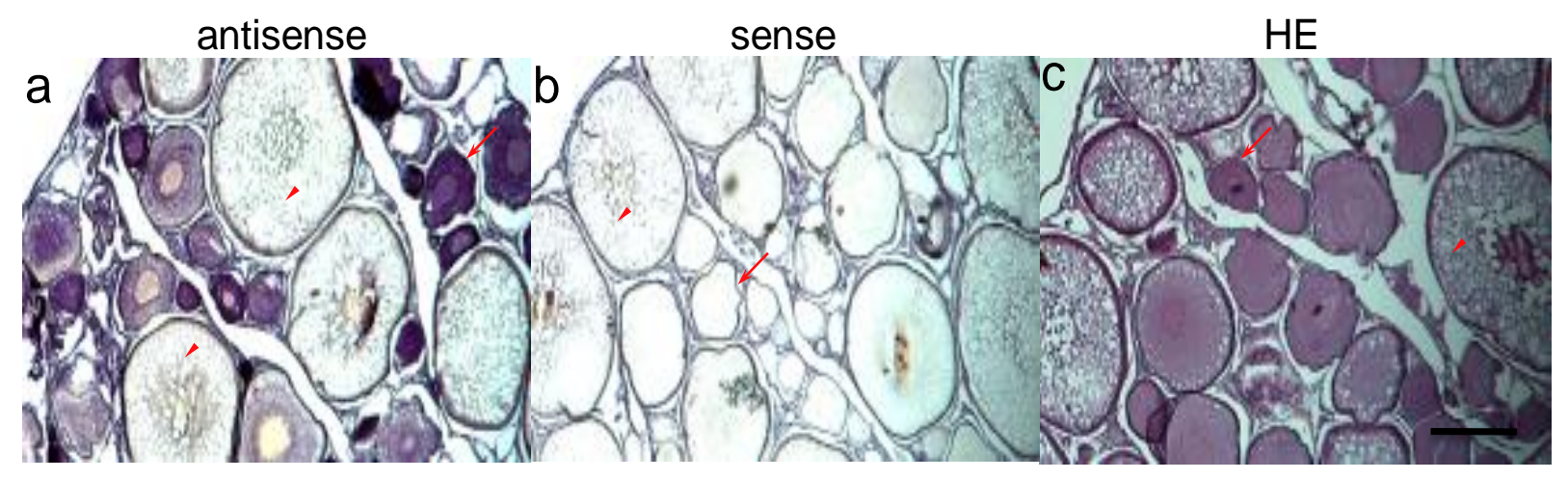

Figure 8 In situ hybridization analysis of Fbos mRNA localization

In situ hybridization (Figure 5. a, b, c) indicated that Fbos is highly expressed in early previtellogenic oocytes at mRNA level. Arrows indicate previtellogenic oocytes, arrow heads indicate vitellogenic oocytes, scale bar $=100 \mu \mathrm{m}$. 
Figure 9.

Fbos primary antibody
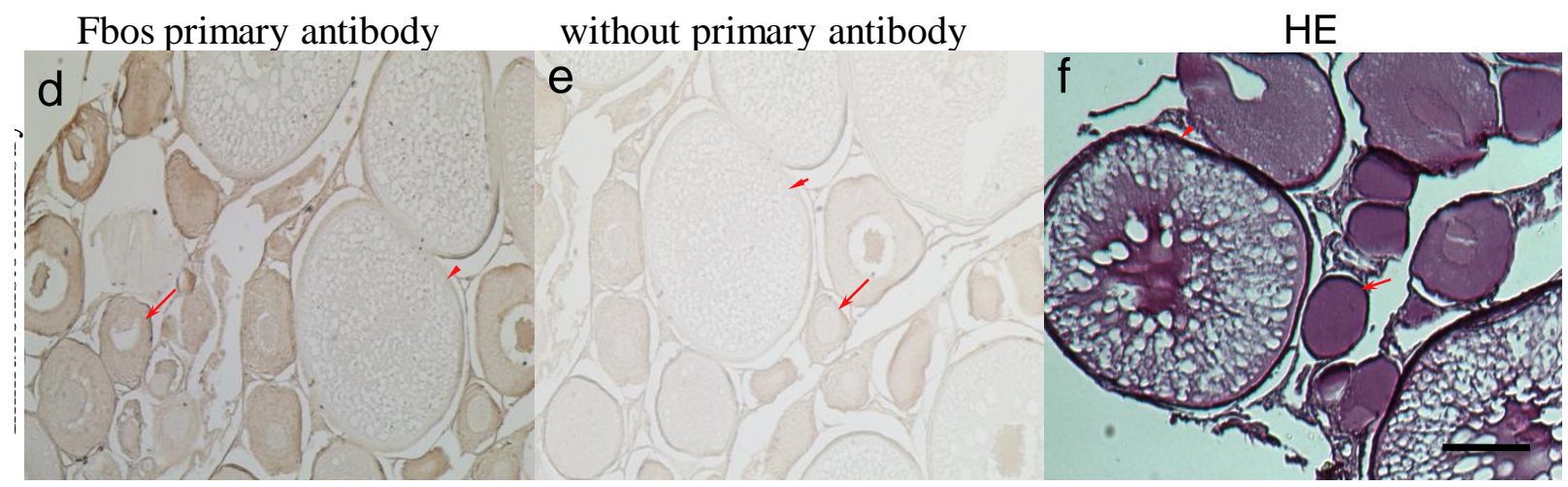

Figure 9 Immunohistochemistry analysis of Fbos protein localization

Immunohistochemistry (Figure 6. d, e, f) indicated that Fbos is highly expressed in early previtellogenic oocytes at protein level. Arrows indicate previtellogenic oocytes, arrow heads indicate vitellogenic oocytes, scale bar $=100 \mu \mathrm{m}$. 
Figure 10.

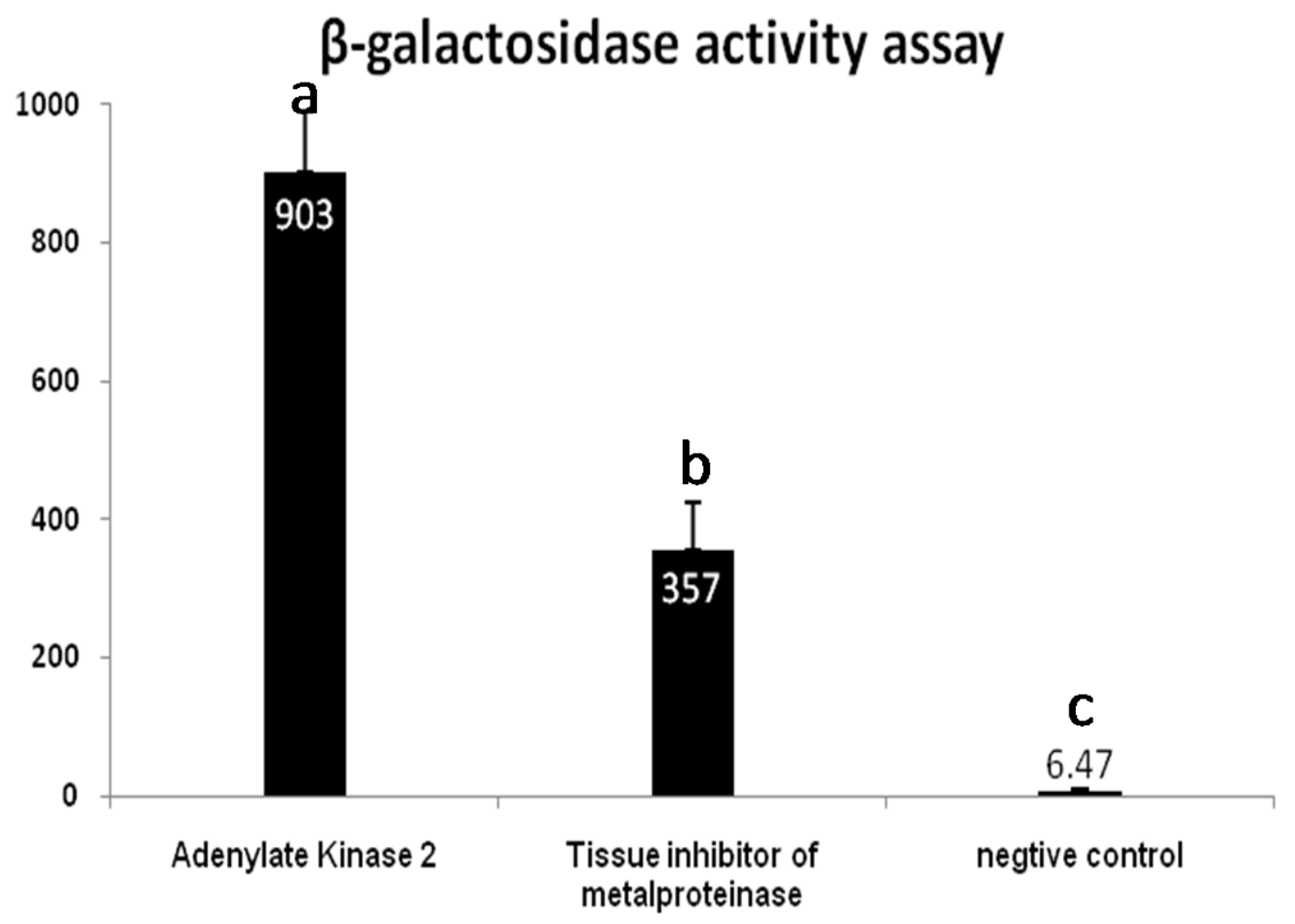

Figure $10 \beta$-galactosidase activity assay of positive colonies from Yeast Two Hybridization analysis

$\beta$-galactosidase activity in yeast cells harboring tissue inhibitor of metalloproteinase and adenylate kinase 2. Negative control was performed using AH109 yeast cell from YPDA plate after incubating in $30^{\circ} \mathrm{C}$ for 3 days. 1 unit of $\beta$-galactosidase was defined as the amount that hydrolyzed $1 \mu \mathrm{mol}$ of CPRG to chlorophenol and D-galactose per minute per cell. 


\section{References}

Aaltonen J, Laitinen MP, Vuojolainen K, Jaatinen R, Horelli-Kuitunen N, Seppa L, Louhio H, Tuuri T, Sjoberg J, Butzow R. 1999. Human Growth Differentiation Factor 9 (GDF-9) and Its Novel Homolog GDF-9B Are Expressed in Oocytes during Early Folliculogenesis 1. Endocrine Soc. pp 2744-2750.

Abida WM, Nikolaev A, Zhao W, Zhang W, Gu W. 2007. FBXO11 Promotes the Neddylation of p53 and Inhibits Its Transcriptional Activity. Journal of Biological Chemistry.

Bai C, Richman R, Elledge SJ. 1994. Human cyclin F. The EMBO Journal 13(24):6087.

Bai C, Sen P, Hofmann K, Ma L, Goebl M, Harper JW, Elledge SJ. 1996. SKP1 connects cell cycle regulators to the ubiquitin proteolysis machinery through a novel motif, the F-box. Cell 86(2):263-274.

Ballow D, Xin Y, Choi Y, Pangas S, Rajkovic A. 2006. Sohlh2 is a germ cell-specific bHLH transcription factor. Gene Expression Patterns 6(8):1014-1018.

Basu D, Navneet AK, Dasgupta S, Bhattacharya S. 2004. Cdc2-cyclin B-induced G2 to M transition in perch oocyte is dependent on Cdc25. Biology of Reproduction 71(3):894.

Bilezikjian LM, Blount AL, Donaldson CJ, Vale WW. 2006. Pituitary actions of ligands of the TGF- $\{$ beta $\}$ family: activins and inhibins. Reproduction 132(2):207.

Bobe J, Labbé C. 2009. Egg and sperm quality in fish. Gen Comp Endocrinol.

Bodensteiner KJ, Clay CM, Moeller CL, Sawyer HR. 1999. Molecular Cloning of the Ovine Growth/Differentiation Factor-9 Gene and Expression of Growth/Differentiation Factor-9 in Ovine and Bovine Ovaries 1. Biology of reproduction 60(2):381-386.

Brenner CA, Adler RR, Rappolee DA, Pedersen RA, Werb Z. 1989. Genes for extracellularmatrix-degrading metalloproteinases and their inhibitor, TIMP, are expressed during early mammalian development. Genes \& development 3(6):848.

Carabatsos MJ, Elvin J, Matzuk MM, Albertini DF. 1998. Characterization of oocyte and follicle development in growth differentiation factor-9-deficient mice. Developmental Biology 204(2):373-384.

Cenciarelli C, Chiaur DS, Guardavaccaro D, Parks W, Vidal M, Pagano M. 1999. Identification of a family of human F-box proteins. Current Biology 9:1177-1179. 
Chiaur D, Guardavaccaro D, Parks W, Vidal M, Pagano M. 1999. Identification of a family of human F-box proteins. Current Biology 9(20):1177-1179.

Choi Y, Qin Y, Berger M, Ballow D, Bulyk M, Rajkovic A. 2007. Microarray analyses of newborn mouse ovaries lacking Nobox. Biology of reproduction 77(2):312.

Clelland ES, Tan Q, Balofsky A, Lacivita R, Peng C. 2007. Inhibition of premature oocyte maturation: A role for Bone Morphogenetic Protein 15 in zebrafish ovarian follicles. Endocrinology 148(11):5451.

Constantinos C. Mylonas AF, Silvia Zanuy. 2009. Broodstock management and hormonal manipulations of fish reproduction. General and Comparative Endocrinology in express.

Coskun S, Lin YC. 1994. Effects of transforming growth factors and activin-A on in vitro porcine oocyte maturation. Molecular Reproduction and Development 38(2).

Craig KL, Tyers M. 1999. The F-box: a new motif for ubiquitin dependent proteolysis in cell cycle regulation and signal transduction. Progress in biophysics and molecular biology 72(3):299-328.

De La Chesnaye E, Kerr B, Paredes A, Merchant-Larios H, Méndez JP, Ojeda SR. 2008. Fbxw15/Fbxo12J is an F-box protein-encoding gene selectively expressed in oocytes of the mouse ovary. Biol Reprod 78(4):714-725.

Deshaies R. 1999. SCF AND C ULLIN/R ING H2-B ASED U BIQUITIN L IGASES. Annual review of cell and developmental biology 15(1):435-467.

Dong J, Albertini DF, Nishimori K, Kumar TR, Lu N, Matzuk MM. 1996. Growth differentiation factor-9 is required during early ovarian folliculogenesis.

Dube JL, Wang P, Elvin J, Lyons KM, Celeste AJ, Matzuk MM. 1998. The bone morphogenetic protein 15 gene is X-linked and expressed in oocytes. Molecular Endocrinology 12(12):18091817.

Durfee T, Roe JL, Sessions RA, Inouye C, Serikawa K, Feldmann KA, Weigel D, Zambryski PC. 2003. The F-box-containing protein UFO and AGAMOUS participate in antagonistic pathways governing early petal development in Arabidopsis. Proceedings of the National Academy of Sciences 100(14):8571-8576.

E Meulmeester RM. 2008. SUMO. Nature 452(10).

Elvin JA, Clark AT, Wang P, Wolfman NM, Matzuk MM. 1999a. Paracrine actions of growth differentiation factor-9 in the mammalian ovary. Molecular Endocrinology 13(6):1035-1048. 
Elvin JA, Yan C, Wang P, Nishimori K, Matzuk MM. 1999b. Molecular characterization of the follicle defects in the growth differentiation factor 9-deficient ovary. Molecular Endocrinology 13(6):1018-1034.

Feng P, Catt KJ, Knecht M. 1988. Transforming growth factor-beta stimulates meiotic maturation of the rat oocyte. Endocrinology 122(1):181.

Ge W. 2005. Intrafollicular paracrine communication in the zebrafish ovary: The state of the art of an emerging model for the study of vertebrate folliculogenesis. Mol Cell Endocrinol 237(12):1-10.

Gomi K, Sasaki A, Itoh H, Ueguchi-Tanaka M, Ashikari M, Kitano H, Matsuoka M. 2004. GID2, an F-box subunit of the SCF E3 complex, specifically interacts with phosphorylated SLR1 protein and regulates the gibberellin-dependent degradation of SLR1 in rice. Plant J 37(4):626634.

Hardie LJ, Laing KJ, Daniels GD, Grabowski PS, Cunningham C, Secombes CJ. 1998. Isolation of the first piscine transforming growth factor gene: analysis reveals tissue specific expression and a potential regulatory sequence in rainbow trout (Oncorhynchus mykiss). Cytokine 10(8):555-563.

Harms CA, Kennedy-Stoskopf S, Horne WA, Fuller FJ, Tompkins WAF. 2000. Cloning and sequencing hybrid striped bass (Morone saxatilis x M. chrysops) transforming growth factor(TGF- ), and development of a reverse transcription quantitative competitive polymerase chain reaction (RT-qcPCR) assay to measure TGF- mRNA of teleost fish. Fish and Shellfish Immunology 10(1):61-85.

Heldin CH, Miyazono K, Ten Dijke P. 1997. TGF- signalling from cell membrane to nucleus through SMAD proteins. NATURE-LONDON-:465-471.

Hershko A, Ciechanover A. 1998. The ubiquitin system. Annual review of biochemistry 67(1):425-479.

Jianping Jin XLA, Takahiro Shirogane, J. Wade Harper. 2005. Indentification of substrates for Fbox proteins. Methods in Enzymology 399.

Johnson E. 2004. PROTEIN MODIFICATION BY SUMO. Annu Rev Biochem 73(1):355-382.

Kajiura-Kobayashi H, Yoshida N, Sagata N, Yamashita M, Nagahama Y. 2000. The Mos/MAPK pathway is involved in metaphase II arrest as a cytostatic factor but is neither necessary nor sufficient for initiating oocyte maturation in goldfish. Development genes and evolution 210(89):416. 
Kamitani T, Kito K, Nguyen H, Yeh E. 1997. Characterization of NEDD8, a developmentally down-regulated ubiquitin-like protein. Journal of Biological Chemistry 272(45):28557-28562.

Kanamori A. 2000. Systematic identification of genes expressed during early oogenesis in medaka. Molecular Reproduction and Development 55(1).

Kipreos ET, Pagano M. 2000. The F-box protein family. Genome Biol.

Kishi T, Ikeda A, Koyama N, Fukada J, Nagao R. A refined two-hybrid system reveals that SCFCdc4-dependent degradation of Swi5 contributes to the regulatory mechanism of S-phase entry. Proceedings of the National Academy of Sciences 105(38):14497.

Kishimoto T. 1994. Cell reproduction: induction of M-phase events by cyclin-dependent cdc2 kinase. The International journal of developmental biology 38(2):185.

Kong M, Barnes E, Ollendorff V, Donoghue D. 2000. Cyclin F regulates the nuclear localization of cyclin B1 through a cyclinñcyclin interaction. The EMBO Journal 19(6):1378-1388.

Laing KJ, Cunningham C, Secombes CJ. 2000. Genes for three different isoforms of transforming growth factor- are present in plaice (Pleuronectes platessa) DNA. Fish and Shellfish Immunology 10(3):261-271.

Laitinen M, Vuojolainen K, Jaatinen R, Ketola I, Aaltonen J, Lehtonen E, Heikinheimo M, Ritvos O. 1998. A novel growth differentiation factor-9 (GDF-9) related factor is co-expressed with GDF-9 in mouse oocytes during folliculogenesis. Mechanisms of development 78(1-2):135140 .

Lessman C. 2009. Oocyte maturation: Converting the zebrafish oocyte to the fertilizable egg. Gen Comp Endocrinol 161(1):53-57.

Liang L, Soyal S, Dean J. 1997. FIGalpha, a germ cell specific transcription factor involved in the coordinate expression of the zona pellucida genes. pp 4939-4947.

Liu L, Ge W. 2007. Growth differentiation factor 9 and its spatiotemporal expression and regulation in the zebrafish ovary. Biology of reproduction 76(2):294.

Margottin-Goguet F, Hsu J, Loktev A, Hsieh H, Reimann J, Jackson P. 2003. Prophase destruction of Emi1 by the SCF TrCP/Slimb ubiquitin ligase activates the anaphase promoting complex to allow progression beyond prometaphase. Developmental Cell 4(6):813-826.

Massague J. 1998. TGF- signal transduction. Annual review of biochemistry 67(1):753-791. 
Matzuk MM, Burns KH, Viveiros MM, Eppig JJ. 2002. Intercellular communication in the mammalian ovary: oocytes carry the conversation. pp 2178-2180.

McIntush EW, Smith MF. 1998. Matrix metalloproteinases and tissue inhibitors of metalloproteinases in ovarian function. Reproduction 3(1):23.

Mulheron GW, Danielpour D, Schomberg DW. 1991. Rat thecal/interstitial cells express transforming growth factor-beta type 1 and 2, but only type 2 is regulated by gonadotropin in vitro. Endocrinology(Philadelphia) 129(1):368-374.

Nagahama Y. 1994. Endocrine regulation of gametogenesis in fish. Int J 0, BioI 38:217-229.

Nagahama Y, Yamashita M. 2008. Regulation of oocyte maturation in fish. Development, Growth \& Differentiation 50(s1 Special ISSUE for the 50th Volume: History and Current Highlights of Developmental Biology):195-219.

Pangas S, Choi Y, Ballow D, Zhao Y, Westphal H, Matzuk M, Rajkovic A. 2006. Oogenesis requires germ cell-specific transcriptional regulators Sohlh1 and Lhx8. Proceedings of the National Academy of Sciences 103(21):8090.

Planas JV, Athos J, Goetz FW, Swanson P. 2000. Regulation of Ovarian Steroidogenesis In Vitro by Follicle-Stimulating Hormone and Luteinizing Hormone During Sexual Maturation in Salmonid Fish 1. Biology of Reproduction 62(5):1262-1269.

Qiu GF, Ramachandra RK, Rexroad CE, Yao J. 2008. Molecular characterization and expression profiles of cyclin B1, B2 and Cdc2 kinase during oogenesis and spermatogenesis in rainbow trout (Oncorhynchus mykiss). Anim Reprod Sci 105(3-4):209-225.

Rajkovic A. 2004. NOBOX Deficiency Disrupts Early Folliculogenesis and Oocyte-Specific Gene Expression. Science 305(5687):1157-1159.

SchmidP CD, vanderPuttenH M. 1994. BilbeG: Expression of TGF-beta s and TGF-beta type II receptor mRNAs in mouse folliculogenesis: Stored maternal TGF-beta 2 message in oocytes. Biochem Biophys Res Commun 201:649-656.

Seiliez I, Panserat S, Skiba-Cassy S, Fricot A, Vachot C, Kaushik S, Tesseraud S. 2008. Feeding status regulates the polyubiquitination step of the ubiquitin-proteasome-dependent proteolysis in rainbow trout (Oncorhynchus mykiss) muscle. Journal of Nutrition 138(3):487.

Sendai Y, Itoh T, Yamashita S, Hoshi H. 2001. Molecular cloning of a cDNA encoding a bovine growth differentiation factor-9 (GDF-9) and expression of GDF-9 in bovine ovarian oocytes and in vitro-produced embryos. Cloning 3(1):3-10. 
Singh B, Barbe GJ, Armstrong DT. 1993. Factors influencing resumption of meiotic maturation and cumulus expansion of porcine oocyte-cumulus cell complexes in vitro. Molecular Reproduction and Development 36(1).

Soyal S, Amleh A, Dean J. 2000. FIGalpha, a germ cell-specific transcription factor required for ovarian follicle formation. pp 4645-4654.

Sumpter JP, Jobling S. 1995. Vitellogenesis as a biomarker for estrogenic contamination of the aquatic environment. Environmental Health Perspectives 103(Suppl 7):173.

Suzumori N, Yan C, Matzuk M, Rajkovic A. 2002. Nobox is a homeobox-encoding gene preferentially expressed in primordial and growing oocytes. Mechanisms of development 111(12):137-141.

Tanaka T, Yamashita M. 1995. Pre-MPF is absent in immature oocytes of fishes and amphibians except Xenopus. Develop Growth Differ 37(4):387-393.

Thorgaard GH, Bailey GS, Williams D, Buhler DR, Kaattari SL, Ristow SS, Hansen JD, Winton JR, Bartholomew JL, Nagler JJ. 2002. Status and opportunities for genomics research with rainbow trout. Comparative Biochemistry and Physiology, Part B 133(4):609-646.

Torres-Padilla ME, Parfitt DE, Kouzarides T, Zernicka-Goetz M. 2007. Histone arginine methylation regulates pluripotency in the early mouse embryo. NATURE-LONDON445(7124):214.

Tyler C, Nagler J, Pottinger T, Turner M. 1994. Effects of unilateral ovariectomy on recruitment and growth of follicles in the rainbow trout, Oncorhynchus mykiss. Fish Physiology and Biochemistry 13(4):309-316.

Tyler CR, Sumpter JP. 1996. Oocyte growth and development in teleosts. Reviews in Fish Biology and Fisheries 6(3):287-318.

Varshavsky A. 1997. The ubiquitin system. Trends in biochemical sciences 22(10):383-387.

Vaur S, Poulhe R, Maton G, And 䦐 1 Y, Jessus C. 2004. Activation of Cdc2 kinase during meiotic maturation of axolotl oocyte. Developmental Biology 267(2):265-278.

Vitt UA, Hsueh AJW. 2002. Stage-dependent role of growth differentiation factor-9 in ovarian follicle development. Molecular and cellular endocrinology 186(2):211-217.

Willems AR, Schwab M, Tyers M. 2004. A hitchhiker's guide to the cullin ubiquitin ligases: SCF and its kin. BBA-Molecular Cell Research 1695(1-3):133-170. 
Yan C, Wang P, DeMayo J, DeMayo FJ, Elvin JA, Carino C, Prasad SV, Skinner SS, Dunbar BS, Dube JL. 2001. Synergistic roles of bone morphogenetic protein 15 and growth differentiation factor 9 in ovarian function. Molecular Endocrinology 15(6):854-866.

Young G, Adachi S, Nagahama Y. 1986. Role of ovarian thecal and granulosa layers in gonadotropin-induced synthesis of a salmonid maturation-inducing substance(17 a, 20 ?dihydroxy-4-pregnen-3-one). Developmental biology(Print) 118(1):1-8.

Zhan Y, Jimmy K. 2000. Molecular isolation and characterisation of carp transforming growth factor 1 from activated leucocytes. Fish and Shellfish Immunology 10(4):309-318.

Zheng P, Dean J. 2007. Oocyte-specific genes affect folliculogenesis, fertilization, and early development. Semin Reprod Med 25(4):243-251. 